\title{
Tritium as an Indicator of Modern, Mixed, and Premodern Groundwater Age
}

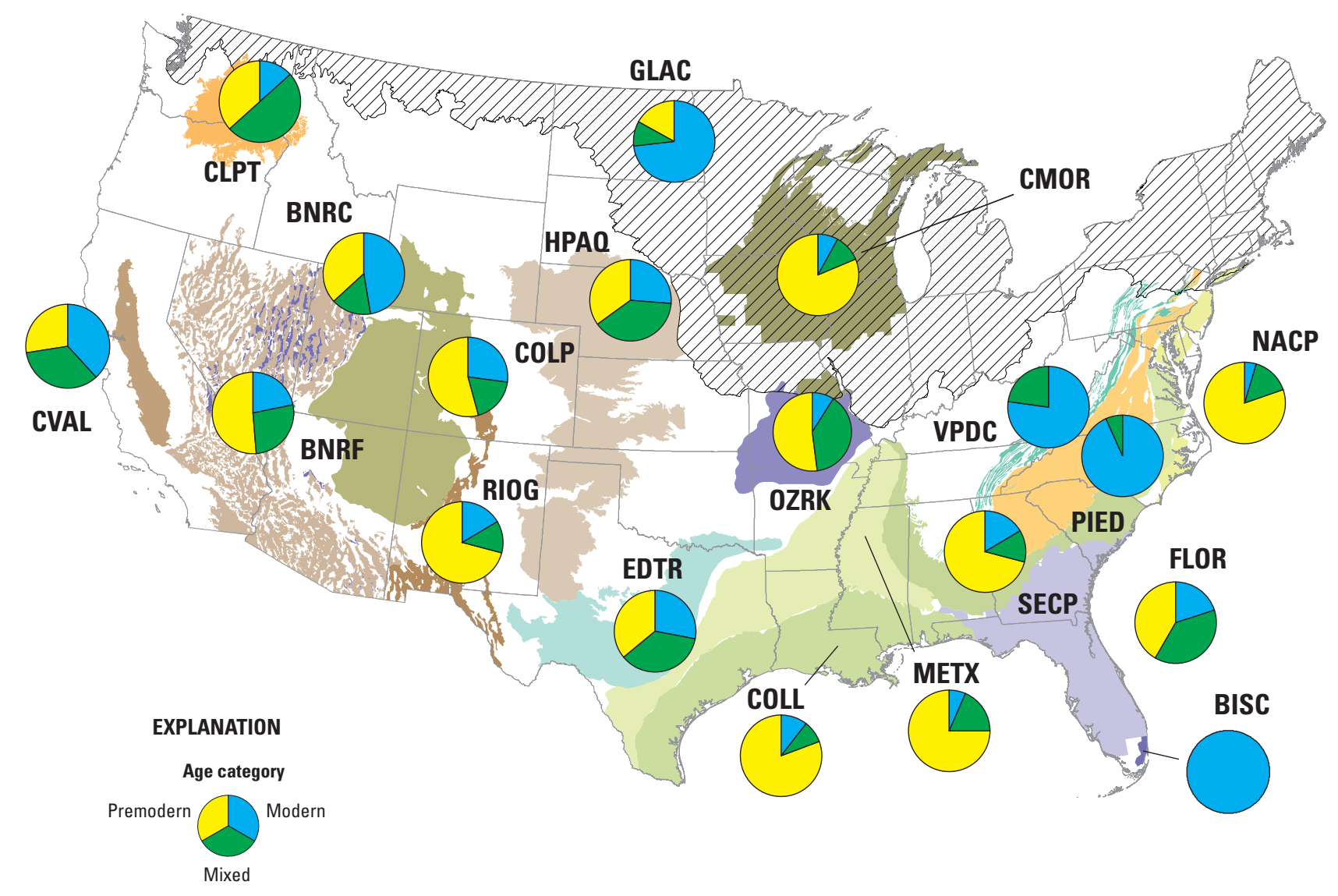

Scientific Investigations Report 2019-5090 
Cover: Image of pie charts showing proportions of modern, mixed, and premodern groundwater for samples from principal aquifers of the United States classified using tritium $\left.{ }^{3} \mathrm{H}\right)$ concentrations. BISC, Biscayne aquifer; BNRC, Basin and Range carbonate-rock aquifers; BNRF, Basin and Range basin fill aquifers; CMOR, Cambrian-Ordovician aquifer system; COLL, Coastal Lowlands aquifers; COLP, Colorado Plateaus aquifers; CPLT, Columbia Plateau basalticrock aquifers; CVAL, Central Valley aquifer system; EDTR, Edwards-Trinity aquifer system; FLOR, Floridan aquifer system; GLAC, Glacial aquifer system; HPA0, High Plains aquifer; METX, Mississippi Embayment/Texas Coastal Uplands aquifer system; NACP, Northern Atlantic Coastal Plain aquifer system; OZRK, Ozark Plateaus aquifer system; PIED, Piedmont and Blue Ridge crystalline-rock aquifers; RIOG, Rio Grande aquifer system; SECP, Southeastern Coastal Plain aquifer system; VPDC, Valley and Ridge/Piedmont and Blue Ridge carbonate-rock aquifers. 


\section{Tritium as an Indicator of Modern, Mixed, and Premodern Groundwater Age}

By Bruce D. Lindsey, Bryant C. Jurgens, and Kenneth Belitz

Scientific Investigations Report 2019-5090 


\title{
U.S. Department of the Interior \\ DAVID BERNHARDT, Secretary
}

\author{
U.S. Geological Survey \\ James F. Reilly II, Director
}

U.S. Geological Survey, Reston, Virginia: 2019

For more information on the USGS - the Federal source for science about the Earth, its natural and living resources, natural hazards, and the environment-visit https://www.usgs.gov or call 1-888-ASK-USGS.

For an overview of USGS information products, including maps, imagery, and publications,

visit https://store.usgs.gov.

Any use of trade, firm, or product names is for descriptive purposes only and does not imply endorsement by the U.S. Government.

Although this information product, for the most part, is in the public domain, it also may contain copyrighted materials as noted in the text. Permission to reproduce copyrighted items must be secured from the copyright owner.

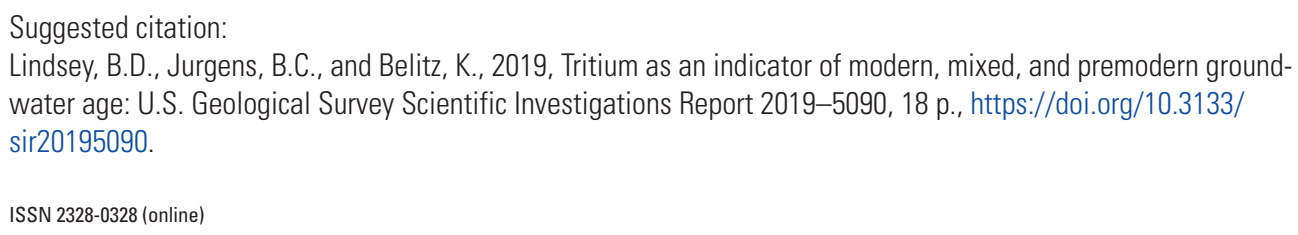




\section{Acknowledgments}

Thanks to the large number of people who collected the samples used in this paper, and the municipalities and individuals who volunteered to have their wells sampled. Thanks to Matthew Landon and Kimberly Beisner, U.S. Geological Survey, for their peer reviews of this report. Also, thanks to the researchers who have provided the data and the framework for this study. 



\section{Contents}

Abstract

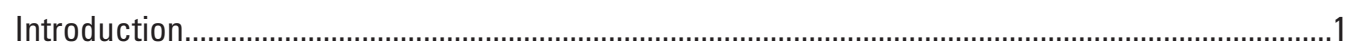

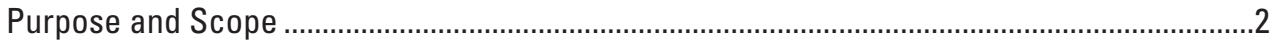

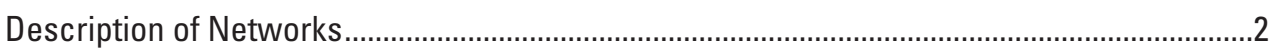

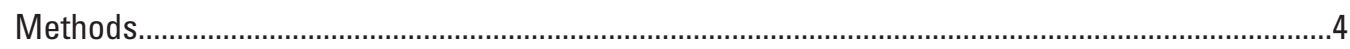

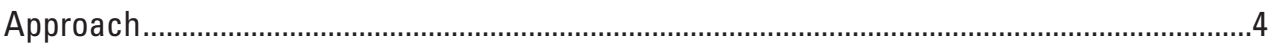

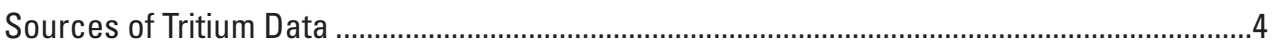

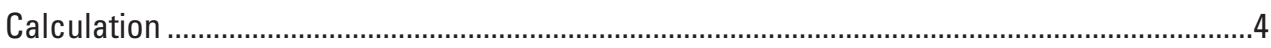

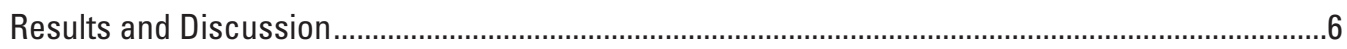

Public-supply Well Results Compared to Hydrogeologic Principles ..........................................6

Nested Pairs of Well Networks with Varying Depths and Climate Conditions...........................8

Public-supply Well Results Compared to Results of Other Age-dating Studies ........................8

Comparison to Similar Approaches ...........................................................................................13

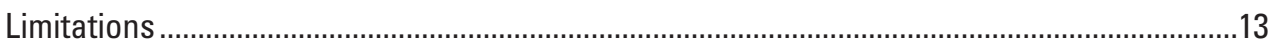

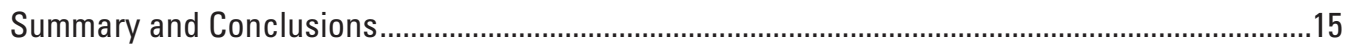

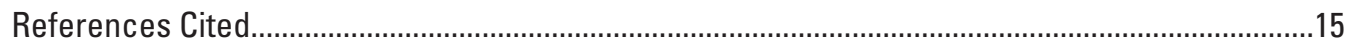

\section{Figures}

1. Map showing estimated tritium deposition over the conterminous United States from Michel and others (2018) ................................................................................

2. Graphs showing tritium in precipitation from 1952 to 2012 for the region defined by $41-43^{\circ} \mathrm{N}$. latitude and $90-95^{\circ} \mathrm{W}$. longitude.

3. Map showing pie charts with proportions of modern, mixed, and premodern groundwater for samples from principal aquifers of the United States classified using tritium concentrations...

4. Map showing locations of modern, mixed, and premodern groundwater for samples from the Southeastern Coastal Plain aquifer system across a range of depths and distances from the outcrop area.....

5. Map showing locations of paired well networks used to compare tritium category results across a range of depth and climate conditions, and pie charts showing proportions of modern, mixed, and premodern groundwater for samples from those networks.

6. Graphs showing percentage of wells in the categories of modern, mixed, and premodern groundwater in this study compared to previous studies in the same aquifer

7. Graphs showing plots of tritium and the tritium/initial tritium ratio for sites where helium isotopes were collected and used to compute tritiogenic helium-3 concentrations.. 


\section{Table}

1. Previous studies of groundwater age that are compared to the results from this study

\section{Conversion Factors}

U.S. customary units to International System of Units

\begin{tabular}{lcl}
\hline \multicolumn{1}{c}{ Multiply } & By & To obtain \\
\hline foot (ft) & Length & meter $(\mathrm{m})$ \\
yard (yd) & 0.3048 & meter $(\mathrm{m})$ \\
\hline & 0.9144 & \\
\hline gallon (gal) & Volume & liter $(\mathrm{L})$ \\
\hline & 3.785 & gram $(\mathrm{g})$ \\
\hline ounce, avoirdupois $(\mathrm{oz})$ & Mass & \\
\hline & 28.35 & becquerel per liter $(\mathrm{Bq} / \mathrm{L})$ \\
\hline picocurie per liter $(\mathrm{pCi} / \mathrm{L})$ & Radioactivity & \\
\hline
\end{tabular}

\section{Specific capacity}

International System of Units to U.S. customary units

\begin{tabular}{|c|c|c|}
\hline Multiply & By & To obtain \\
\hline \multicolumn{3}{|c|}{ Length } \\
\hline meter $(\mathrm{m})$ & 3.281 & foot $(\mathrm{ft})$ \\
\hline meter $(\mathrm{m})$ & 1.094 & yard (yd) \\
\hline \multicolumn{3}{|c|}{ Volume } \\
\hline liter $(\mathrm{L})$ & 0.2642 & gallon (gal) \\
\hline \multicolumn{3}{|c|}{ Radioactivity } \\
\hline becquerel per liter $(\mathrm{Bq} / \mathrm{L})$ & 27.027 & picocurie per liter $(\mathrm{pCi} / \mathrm{L})$ \\
\hline
\end{tabular}

Temperature in degrees Celsius $\left({ }^{\circ} \mathrm{C}\right)$ may be converted to degrees Fahrenheit ( $\left.{ }^{\circ} \mathrm{F}\right)$ as follows:

$$
{ }^{\circ} \mathrm{F}=\left(1.8 \times{ }^{\circ} \mathrm{C}\right)+32 \text {. }
$$

Temperature in degrees Fahrenheit $\left({ }^{\circ} \mathrm{F}\right)$ may be converted to degrees Celsius $\left({ }^{\circ} \mathrm{C}\right)$ as follows:

$$
\left.{ }^{\circ} \mathrm{C}=\left({ }^{\circ} \mathrm{F}-32\right) / 1.8 .32\right) / 1.8 \text {. }
$$




\section{Supplemental Information}

Concentrations of chemical constituents in water are given in either milligrams per liter (mg/L) or micrograms per liter $(\mu \mathrm{g} / \mathrm{L})$.

Activities for radioactive constituents in water are given in picocuries per liter ( $\mathrm{pC} \mathrm{C} / \mathrm{L}$ ).

Results for measurements of stable isotopes of an element (with symbol E) in water, solids, and dissolved constituents commonly are expressed as the relative difference in the ratio of the number of the less abundant isotope (iE) to the number of the more abundant isotope of a sample with respect to a measurement standard.

\section{Abbreviations}

${ }^{14} \mathrm{C}$

CONUS

GAMA

${ }^{3} \mathrm{H}$

${ }^{3} \mathrm{He}$

NAWQA

TU

USGS carbon-14

conterminous United States

Groundwater Ambient Monitoring and Assessment priority basin project

tritium

tritiogenic helium-3

National Water-Quality Assessment Project

tritium units

U.S. Geological Survey 



\title{
Tritium as an Indicator of Modern, Mixed, and Premodern Groundwater Age
}

\author{
By Bruce D. Lindsey, Bryant C. Jurgens, and Kenneth Belitz
}

\section{Abstract}

Categorical classification of groundwater age is often used for the assessment and understanding of groundwater resources. This report presents a tritium-based age classification system for the conterminous United States based on tritium $\left({ }^{3} \mathrm{H}\right)$ thresholds that vary in space and time: modern (recharged in 1953 or later), if the measured value is larger than an upper threshold; premodern (recharged prior to 1953) if the measured value is smaller than a lower threshold; or mixed if the measured value is between the two thresholds. Inclusion of spatially varying thresholds, rather than a single threshold, accounts for the observed systematic variation in ${ }^{3} \mathrm{H}$ deposition across the United States. Inclusion of time-varying thresholds, rather than a single threshold, accounts for the date of sampling given the radioactive decay of ${ }^{3} \mathrm{H}$.

The efficacy of the tritium-based age classification system was evaluated at national and regional scales. The system was evaluated at a national scale by classifying samples from 1,788 public-supply wells distributed across 19 principal aquifers and comparing those results with expectations based on hydrogeologic principles. The regional-scale data are from five paired networks of shallow and deep wells (287 wells). As expected, modern groundwater is more prevalent in shallow wells than in deeper wells, in fractured-rock and carbonate aquifers as compared to clastic aquifers, in unconfined areas as compared to confined areas, and in humid climates as compared to arid climates. The results from a tritium-based age classification system compared favorably with the results of 14 previous studies of groundwater ages that used different age tracers and analytical methods. The wells and samples from the Cambrian-Ordovician aquifer that had been analyzed using a more complex multi-tracer analysis were also analyzed using the tritium-based age classification system, and there was a close match between the two methods. The results from these various studies suggest that the tritium-based age classification system may be informative as a screening tool prior to selecting more expensive and complex age-dating tracers and methods, or to provide an explanatory variable for other water-quality data where more complex methods or tracers are not available.

This work improves on previous groundwater age classification using ${ }^{3} \mathrm{H}$ by developing methods that (1) determine
${ }^{3} \mathrm{H}$ thresholds for groundwater recharged in 1953 or later that minimize the misclassification of modern samples as mixed; (2) determine a pre-1953 threshold to estimate premodern background concentrations; and (3) add a mixed category to classify samples that are clearly neither entirely modern nor entirely premodern. As with any tritium-based approach, it can fail when the ${ }^{3} \mathrm{H}$ record in precipitation does not accurately reflect the record of ${ }^{3} \mathrm{H}$ in recharge.

\section{Introduction}

Estimates of groundwater age are often used to enhance groundwater studies. Groundwater age is used to estimate recharge rates (McMahon and others, 2011), to calibrate groundwater models (Sheets and others, 1998; Starn and others, 2010; Sanford, 2011), and to infer susceptibility of groundwater to contamination by activities at the land surface (Böhlke and Denver, 1995; Broers, 2004; Seifert and others, 2007; Landon and Belitz, 2012; McMahon, 2012). In studies of groundwater quality, recently recharged groundwater is commonly considered to be susceptible to contamination by persistent, soluble anthropogenic contaminants introduced at the land surface. Conversely, concentrations of naturally occurring contaminants can be elevated in premodern groundwater because they dissolve from aquifer materials over long time periods.

Methods for incorporating age-dating tracers into groundwater studies range from simple to complex. The selection of the tracers and the complexity of the interpretation of those tracers depend on the objectives of any given study. The simplest methods use binary bins of modern (post-1950s) and premodern (pre-1950s) by comparing the concentration of an atmospheric tracer like tritium $\left({ }^{3} \mathrm{H}\right)$ to a selected threshold; for example, McMahon (2012) used a concentration threshold of ${ }^{3} \mathrm{H}$ greater than or less than 0.5 tritium unit (TU) to differentiate modern from premodern water, whereas Thomas (2007) used 1 TU. Carbon-14 $\left({ }^{14} \mathrm{C}\right)$ has also been used to date premodern groundwater (Vogel, 1967; Mook, 1980; Sudicky and Frind, 1981). In a study in the Salt Lake Basin of Utah, Manning and others (2005) and Thiros and Manning (2004) assigned modern, mixed, and premodern (called pre-bomb in those reports) groundwater ages using ${ }^{3} \mathrm{H}$ and tritiogenic 
helium-3 $\left({ }^{3} \mathrm{He}_{\text {trit }}\right)$ measurements. Samples with concentrations of tritium that were less than 80 percent of the expected value were assigned to the mixed category, and concentrations less than $2 \mathrm{TU}$ were classified as premodern. Their classification system was successful in identifying groundwater with a greater likelihood of having modern water, and subsequently with higher concentrations and occurrences of contaminants (Manning and others, 2005). Screening methods using ${ }^{3} \mathrm{H}$ are often helpful to determine whether more sophisticated methods are warranted.

More complex methods include the use of multiple atmospheric tracers such as chlorofluorocarbons (CFCs) (Plummer and Busenberg, 1999), sulfur hexafluoride $\left(\mathrm{SF}_{6}\right)$ (Busenberg and Plummer, 2000), tritium-helium $\left({ }^{3} \mathrm{H} /{ }^{3} \mathrm{He}\right.$ ) (Schlosser and others, 1988; Solomon and others, 1992), and ${ }^{14} \mathrm{C}$ to determine an apparent piston-flow age or a mean age. Lumped parameter models such as TracerLPM (Jurgens and others, 2012) and numerous other models as described in Turnadge and Smerdon (2014) use multiple tracers to determine the residence time distribution in a given well. Lumped parameter models that describe the residence-time distribution of flow into a well can be used to predict the arrival and eventual attenuation of a contaminant in that well (McMahon and others, 2008; Lindsey and others, 2017). However, these methods require multiple tracers, which may not always be available, so more simple age classification methods are still desirable.

Tritium is a radioactive isotope of hydrogen (half-life 12.32 years; Lucas and Unterweger, 2000). Because of the rapid increase and decrease of ${ }^{3} \mathrm{H}$ in precipitation during and after the period of atmospheric nuclear-weapons testing, it is often used to differentiate groundwater recharged before and after the early 1950s (Thomas, 2007; Thiros and Manning, 2004; McMahon, 2012). This binary system of classification for modern (post-1950s) and premodern (pre-1950s) groundwater requires a single threshold value, which is based on an estimate of the pre-bomb value of ${ }^{3} \mathrm{H}$ in precipitation and then corrected for decay to the date of sampling. This binary classification system is most useful for identifying groundwater that is predominately premodern, whereas the modern category may be more ambiguous because many modern samples include a mixture of both modern and premodern water. A tritium-based age classification system that differentiates a groundwater sample that is clearly mixed from a modern one would be advantageous. In practice, classification systems cannot perfectly distinguish between these age classes of water, rather the classification systems should differentiate less ambiguous water from more ambiguous ages of water. For example, premodern samples may contain small amounts of modern water, so a threshold can be chosen to minimize the modern fraction such that samples have chemical characteristics similar to other premodern samples.

Regardless of classification approach, ${ }^{3} \mathrm{H}$ thresholds can lead to misclassifications when thresholds do not account for the spatial and temporal variability of ${ }^{3} \mathrm{H}$ deposition in precipitation. Michel and others (2018) recently published data on ${ }^{3} \mathrm{H}$ concentrations in precipitation for the conterminous
United States (CONUS) (fig. 1). This dataset accounts for large-scale spatial and temporal patterns in the concentration of ${ }^{3} \mathrm{H}$ in precipitation so that regional thresholds for classifying groundwater can be made.

The tritium-based age classification system introduced in this report is useful in evaluating groups of wells with similar characteristics to provide a general or preliminary understanding of groundwater age in a given aquifer or region. Although the method described herein uses the data from Michel and others (2018), it could be used with other records of ${ }^{3} \mathrm{H}$ in precipitation from a given region of interest. For example, Eastoe and others (2012) evaluated ${ }^{3} \mathrm{H}$ in precipitation in the southwestern United States at a finer regional scale than Michel and others (2018) and accounted for factors such as regional nuclear testing and altitude, whereas Jasechko (2016) used a global dataset with a coarser temporal and geographic resolution. The most accurate available record of ${ }^{3} \mathrm{H}$ in precipitation will provide the best results with this method. In the method presented here, thresholds were computed for half-year increments so that ${ }^{3} \mathrm{H}$ measurements could be evaluated using the most appropriate threshold for the date the sample was collected. Tritium sampling analysis using this method could be used as a screening tool to determine the need for further tracer sampling. The method herein is similar to that described by Jasechko (2016), who describes a technique using ${ }^{3} \mathrm{H}$ to quantify the proportion of a sample that has recharged since 1953.

\section{Purpose and Scope}

The purpose of this report is to present a tritium-based age classification system for determining age categories of modern, mixed, or premodern for groundwater based on the concentration of ${ }^{3} \mathrm{H}$ in a sample, the sample date and location, and the reconstructed input curve of ${ }^{3} \mathrm{H}$ in precipitation for that region of the CONUS. This method is applied to ${ }^{3} \mathrm{H}$ samples from 1,788 public-supply wells distributed across 19 principal aquifers of the United States and 287 wells in 5 paired land use and domestic-supply well networks (shallow and deeper wells, respectively) distributed across different aquifer types and climate zones of the United States. We evaluate the utility of this method by comparing cohorts of data among different aquifer types, confinement, climate zones, and well depths. We also compare results of this study to results from 14 previously published studies that calculated groundwater age using multiple age-dating tracers. Tritium samples in groundwater were collected from 1997 to 2017.

\section{Description of Networks}

The 19 networks of public-supply wells included in this study represent principal aquifers that rank among the highest in the Nation for public and domestic water-supply withdrawals (Maupin and Barber, 2005). Public-supply well networks were designed using a stratified-random selection program 


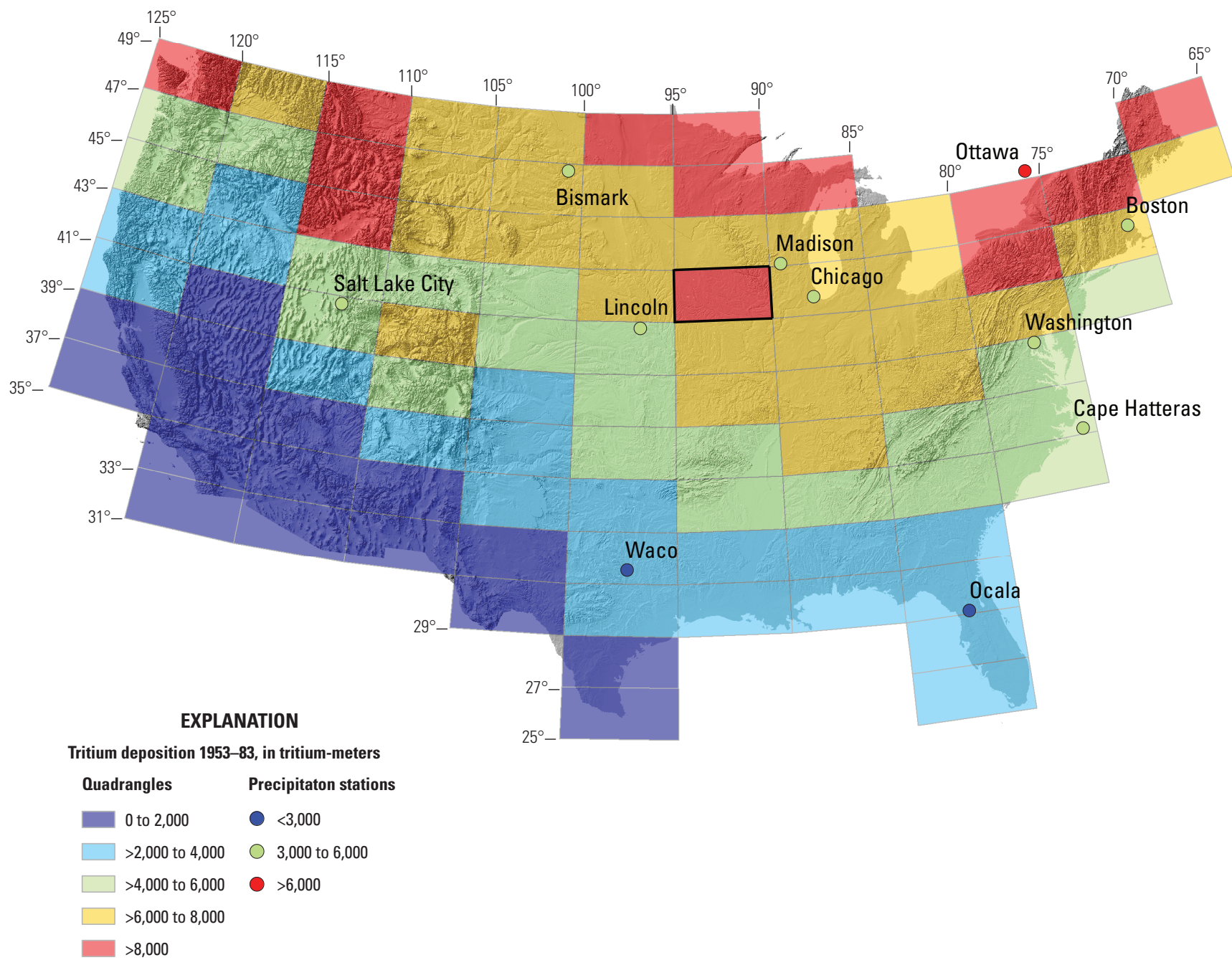

Figure 1. Estimated tritium $\left({ }^{3} \mathrm{H}\right)$ deposition over the conterminous United States from Michel and others (2018). Deposition since 1983 is negligible and the pattern of deposition through 2012 would be similar to that shown.

(Scott, 1990) and wells were sampled across the spatial extent of each principal aquifer. The number of wells per principal aquifer ranged from 20 to 132 , but typically $60-80$ wells were selected in each principal aquifer. Tritium data from all but one of the 19 principal aquifers are from the U.S. Geological Survey (USGS) National Water-Quality Assessment (NAWQA) Project. Samples representing the Central Valley aquifer system in California are from the Groundwater Ambient Monitoring and Assessment priority basin project (GAMA); however, studies in the Central Valley were designed using the same approach as was used in the NAWQA Project. Data from the GAMA project were collected from 2006 to 2010; the design of the GAMA networks is described in Belitz and others (2003). Data used in this report are available in Lindsey and others (2019).

The five pairs of networks representing nested shallow and deep aquifers are from the USGS NAWQA Project's landuse and major aquifers studies. These studies represent small regions of principal aquifers, and in the case of the land-use studies, wells are selected representing specific land-uses such as urban or agricultural. Each pair of networks includes one network with relatively shallow well depths and another with relatively deep well depths. Typically, the shallow wells are monitoring wells and the deeper wells are domestic-supply wells. The five networks are located in different climate regions across the country. 


\section{Methods}

\section{Approach}

The concept for the tritium-based age classification system is based on a general understanding of how concentrations of ${ }^{3} \mathrm{H}$ in groundwater vary given the temporal variation of ${ }^{3} \mathrm{H}$ in precipitation. Prior to $1953,{ }^{3} \mathrm{H}$ concentrations in precipitation were at low, naturally occurring levels, but subsequently increased rapidly owing to above-ground nuclear bomb testing (Michel, 1989). Concentrations in precipitation remained elevated for several decades. Recently, concentrations have leveled off in the range estimated to exist under natural conditions (2-10 TU; Stewart and Hoffman, 1966), suggesting a return to near pre-bomb concentrations. However, ${ }^{3} \mathrm{H}$ concentrations in a groundwater sample recharged prior to 1953 are much lower than a sample recharged in the post-peak era because of the decay of ${ }^{3} \mathrm{H}$ between 1953 and the date of collection of the sample. Thus, it is possible to calculate a value for ${ }^{3} \mathrm{H}$ below which a sample can be determined to have been recharged prior to 1953. In addition, concentrations from a groundwater sample that are greater than any of the lowest post-peak concentrations in precipitation (when decayed to the date of sampling) must have been recharged in 1953 or later. This leaves a range of concentrations that are between the upper and lower threshold that can only be the result of a mixture of modern and premodern water.

\section{Sources of Tritium Data}

The International Atomic Energy Agency Global Network of Isotopes in Precipitation is the main repository for records of ${ }^{3} \mathrm{H}$ in precipitation for stations across the world and in the United States. Although only a small number of stations continue to collect data, many of these stations collected monthly precipitation samples for ${ }^{3} \mathrm{H}$ from the 1950s through the 1980s (International Atomic Energy Agency, 2017). These stations show that ${ }^{3} \mathrm{H}$ in precipitation varies spatially and temporally throughout the world and can be higher or lower than yearly or seasonal global averages depending on latitude and longitude and how precipitation events are influenced by tropospheric and oceanic air masses. Monthly ${ }^{3} \mathrm{H}$ activities were interpolated to 2-degree latitude by 5-degree longitude grid cells covering the CONUS to reconstruct ${ }^{3} \mathrm{H}$ in precipitation for areas where ${ }^{3} \mathrm{H}$ in precipitation was not collected (Michel and others, 2018). Michel and others showed that ${ }^{3} \mathrm{H}$ deposition can be more than four times higher at northern latitudes $\left(45-47^{\circ}\right)$ than in southern latitudes $\left(29-31^{\circ}\right)$ at longitudes in the middle of the continent $\left(100-105^{\circ}\right)$. Likewise, ${ }^{3} \mathrm{H}$ deposition in the western United States is generally lower than in the east because precipitation in the west is derived from ocean moisture that contains less ${ }^{3} \mathrm{H}$, whereas air masses traveling across or originating within the CONUS can be influenced by stratospheric air that contains more ${ }^{3} \mathrm{H}$ (Michel and others, 2018). However, there is some evidence of stratospheric
${ }^{3} \mathrm{H}$ input to stations measured in Arizona and New Mexico (Eastoe and others, 2012). Intra-annual variability of ${ }^{3} \mathrm{H}$ activities at a station has been shown to fluctuate several tritium units (TU) over the last few decades but is, on average, about 2 TU for recent data (2008-12).

\section{Calculation}

Given a measurement of ${ }^{3} \mathrm{H}$ in a groundwater sample and the estimated time-series record of ${ }^{3} \mathrm{H}$ in precipitation for the location of the sample (Michel and others, 2018), thresholds can be calculated for modern and premodern groundwater. Laboratory results in picocuries per liter are converted to tritium units using the conversion 1 picocurie per liter $=0.313 \mathrm{TU}$. The estimates of ${ }^{3} \mathrm{H}$ in precipitation vary by latitude and longitude and the thresholds vary based the year of the tritium sample (fig. $2 A$ ). In this study, the premodern threshold is a value of ${ }^{3} \mathrm{H}$ that indicates recharge prior to 1953 and modern is considered to be recharged in 1953 or later. Because measurements of background (pre-bomb) ${ }^{3} \mathrm{H}$ are not available, an estimate is made by calculating concentrations during the recent period of 2008-12, when concentrations had largely stabilized. The modern threshold is a value of ${ }^{3} \mathrm{H}$ that indicates the groundwater was recharged in 1953 or later. In order to have a measured ${ }^{3} \mathrm{H}$ concentration in a groundwater sample that is greater than that threshold, the water must have entered the aquifer in 1953 or later.

The procedure for determining and applying the thresholds are as follows:

1. Determine a modern threshold. For each value of ${ }^{3} \mathrm{H}$ in the precipitation record for the geographic region of interest, calculate a decayed concentration of ${ }^{3} \mathrm{H}$ based on the time span between the date of the precipitation value and the date of the groundwater ${ }^{3} \mathrm{H}$ sample. The modern threshold is set at the minimum post-peak concentration of decayed ${ }^{3} \mathrm{H}$ in precipitation. We compute the modern threshold based on semiannual (half-year) ${ }^{3} \mathrm{H}$ values so that some intra-annual variability is captured and large fluctuations of monthly data are dampened.

2. Determine a premodern threshold. Calculate the average concentration of ${ }^{3} \mathrm{H}$ in precipitation from the 2008-12 period of record (to use as an estimate of ${ }^{3} \mathrm{H}$ concentration in 1952), then calculate the decay of that ${ }^{3} \mathrm{H}$ concentration from 1952 to the date of the groundwater ${ }^{3} \mathrm{H}$ sample; this is the threshold below which groundwater is considered premodern.

3. Concentrations of ${ }^{3} \mathrm{H}$ in groundwater that are between the premodern and modern thresholds are considered mixed. A sample would have to contain some fractions of premodern and modern groundwater to fall between these thresholds. This approach assumes ${ }^{3} \mathrm{H}$ travels through the aquifer under piston-flow behavior. This assumption is made because it will give the maximum 

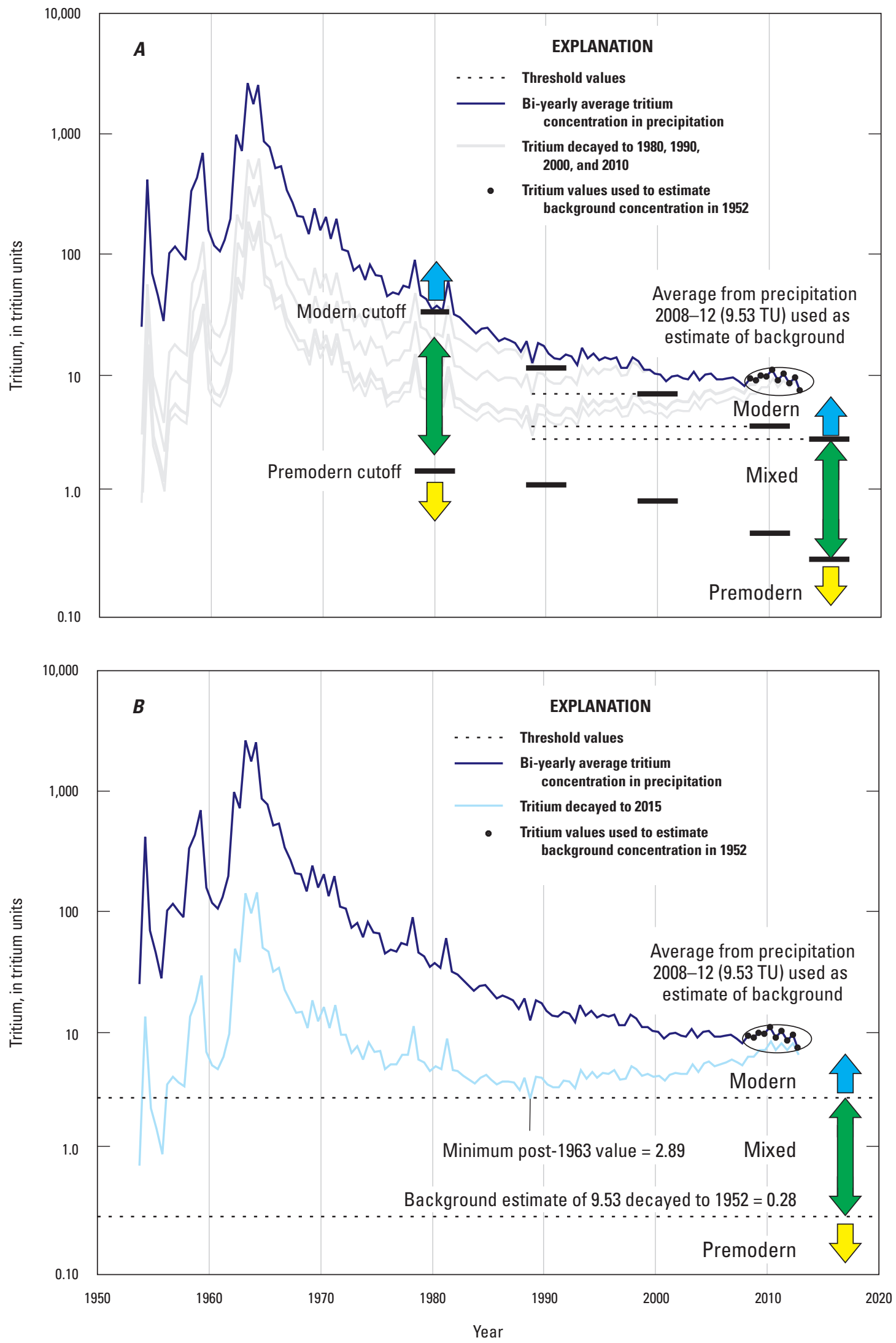

Figure 2. Tritium $\left({ }^{3} \mathrm{H}\right)$ in precipitation from 1952 to 2012 for the region defined by $41-43^{\circ} \mathrm{N}$. latitude and $90-95^{\circ} \mathrm{W}$. longitude. $(A)$ Initial ${ }^{3} \mathrm{H}$ in precipitation decayed to the years 1980, 1990, 2000, and 2010, and thresholds for modern, mixed, and premodern categories for ${ }^{3} \mathrm{H}$ concentrations in groundwater measured in this region; and $(B)$ example illustrating thresholds for the year 2015. 
concentration for the premodern threshold and a minimum concentration for the modern threshold. Any mixing that occurs within an aquifer would tend to lower the ${ }^{3} \mathrm{H}$ threshold of the premodern period and increase the ${ }^{3} \mathrm{H}$ threshold of the modern period. An example illustrating the process for a sample from $41-43^{\circ} \mathrm{N}$. latitude and $90-95^{\circ} \mathrm{W}$. longitude for the year 2015 is shown in figure $2 B$.

The classification of groundwater age is dependent on reasonably accurate compilations of the reconstructed ${ }^{3} \mathrm{H}$ record in local precipitation. Recently, Michel and others (2018) computed reconstructed records of ${ }^{3} \mathrm{H}$ in precipitation for $2^{\circ}$ latitude by $5^{\circ}$ longitude sections of the CONUS (fig. 1). This comprehensive dataset provides estimates of regional ${ }^{3} \mathrm{H}$ records that can be used for computing spatially and time-varying thresholds for premodern and modern groundwater across the CONUS. Because the ${ }^{3} \mathrm{H}$ records cover a large area, local precipitation can deviate from the regional estimate. This uncertainty in ${ }^{3} \mathrm{H}$ records is greater along the eastern and southern coasts where ocean weather patterns can dilute the ${ }^{3} \mathrm{H}$ in precipitation estimated by Michel and others (2018). Comparisons between the reconstructed ${ }^{3} \mathrm{H}$ record and local ${ }^{3} \mathrm{H}$ measurements are limited, but ${ }^{3} \mathrm{H}$ in precipitation between 2000 and 2008 at Cape Hatteras, North Carolina, were lower than reconstructed ${ }^{3} \mathrm{H}$ by about 45 percent. In other places, such as Washington D.C., the reconstructed ${ }^{3} \mathrm{H}$ record closely approximates the yearly average even though intra-annual variability is not fully captured (Michel and others, 2018).

An example calculation of the thresholds was done using the ${ }^{3} \mathrm{H}$ in precipitation record for the grid cell defined by $43-41^{\circ} \mathrm{N}$. latitude and $95-90^{\circ} \mathrm{W}$. longitude (fig. $2 B$ ). In this area, the decay of the initial concentration in precipitation (dark blue line) is calculated based on the time span between the year of each precipitation to the year of interest (light blue line) or the year a ${ }^{3} \mathrm{H}$ sample is collected (2015 in this example). When the concentrations in precipitation are decayed to 2015 , the minimum post-peak value in this example is $2.89 \mathrm{TU}$. The average of 2008-12 values is $9.53 \mathrm{TU}$, which is used to estimate probable ${ }^{3} \mathrm{H}$ concentrations in 1952. This estimated premodern concentration decayed to 1952 is $0.28 \mathrm{TU}$ (fig. $2 B$ ). We can then compare ${ }^{3} \mathrm{H}$ measurements in groundwater in this geographic region collected in 2015 to these thresholds. Measured concentrations of greater than 2.89 TU are considered modern - that is, recharged in 1953 or later. Water with concentrations less than $0.28 \mathrm{TU}$ are classified as premodern - that is, recharged prior to 1953 . Water with concentrations between the upper and lower threshold, in this case $0.28-2.89 \mathrm{TU}$, are classified as mixtures of modern and premodern water.

This tritium-based age classification system identifies premodern and mixed groundwater samples less ambiguously than modern groundwater samples. Premodern samples are primarily composed of groundwater recharged before 1953 but can still contain small fractions of modern groundwater, however, this fraction will be much less than 10 percent. Modern samples, on the other hand, can have sizable fractions of premodern water depending on the actual age of the modern water in the mixture and the date of sample collection. Therefore, samples with ${ }^{3} \mathrm{H}$ above the modern threshold can be misclassified as modern when the sample is in fact mixed. In the classification system developed here, mixed samples are unlikely to be misclassified because the sample has tritium concentrations indicative of premodern and modern water. The limitations of this classification system are discussed further in the Limitations section.

\section{Results and Discussion}

The approach presented in the previous section was tested using ${ }^{3} \mathrm{H}$ concentrations measured in samples collected from public water-supply wells, domestic-supply wells, and monitoring wells in the CONUS as part of the USGS NAWQA Project. Each well with a ${ }^{3} \mathrm{H}$ concentration was compared to the threshold for its respective region and sampling date, and assigned a category of modern, mixed, or premodern. This dataset spans a wide range of climatic regions, geographic regions, hydrogeologic settings, aquifers, and well depths. We apply the age category criteria to these measurements and evaluate whether the results are consistent with a general understanding of the hydrogeology of the aquifers. For example, ages are expected to be older in deeper groundwater when compared to shallow groundwater, in arid regions when compared to humid regions, and in confined aquifers when compared to unconfined aquifers. Also, carbonate-bedrock aquifers and fractured rock aquifers are expected to have younger groundwater ages than other aquifer types. The categorical approach for age classification is most useful for understanding cohorts of data from sets of wells grouped by common characteristics rather than results from individual wells.

To test the utility of this method, we evaluate ${ }^{3} \mathrm{H}$ measurements in groundwater from a large range of aquifer types from the NAWQA Project. We compare these results to expectations relative to a general understanding of hydrogeology and results of other groundwater age-dating studies in that aquifer or region. We also compare results to previously reported groundwater ages.

\section{Public-supply Well Results Compared to Hydrogeologic Principles}

The efficacy of the tritium-based age classification system developed in this report can be assessed by examining data collected at a national scale. Between 2004 and 2017, ${ }^{3} \mathrm{H}$ was analyzed in samples from 1,788 public-supply wells that withdraw water from one of 19 principal aquifers (U.S. Geological Survey, 2003). Public-supply wells were distributed across equal-area grids, each of which covered the principal aquifers, 
to provide a statistically unbiased assessment of each aquifer. Thus, proportions of modern, mixed, and premodern groundwater in each principal aquifer provide meaningful estimates of the groundwater resource used for public supply (fig. 3).

Consistent with hydrogeologic expectations, unconfined carbonate and crystalline aquifers in the humid eastern United States have the largest proportions of modern water: unconfined Biscayne (BISC), Valley and Ridge/Piedmont and Blue Ridge carbonate (VPDC), and Piedmont and Blue Ridge crystalline (PIED) (fig. 3). The unconfined carbonate aquifer in an arid region (Basin and Range carbonate, BNRC) has a high proportion of modern water compared to other aquifers in the region, but less than the unconfined carbonate-rock aquifers in humid regions (BISC, VPDC), likely a result of lower recharge rates and deeper flow paths. Carbonate aquifers that have both confined and unconfined conditions (Floridan aquifer system, FLOR; and Edwards-Trinity aquifer system, EDTR) have more premodern groundwater than the unconfined carbonate aquifers, but when we evaluate the unconfined part of those aquifers, they have a high proportion of modern

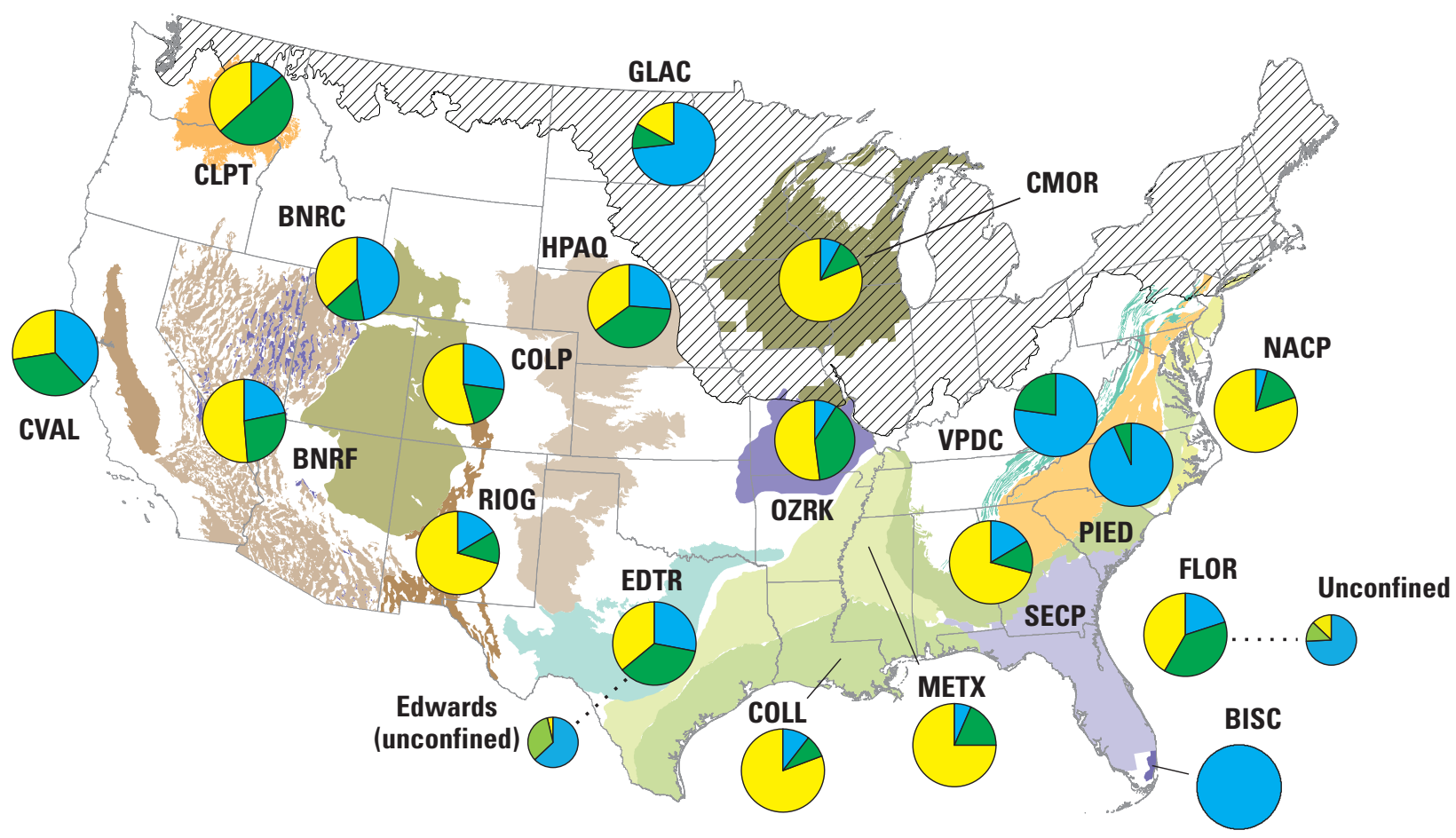

EXPLANATION

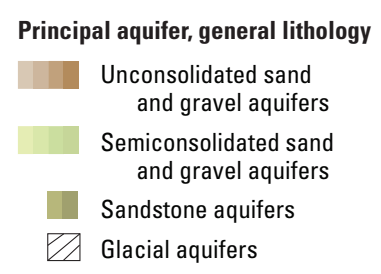

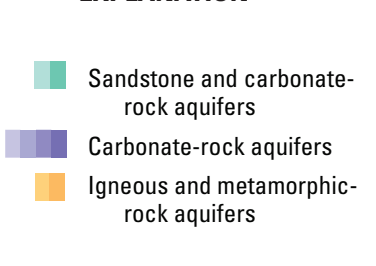

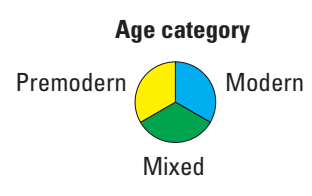

(2) 
and mixed groundwater, similar to the other unconfined carbonate aquifers (BISC, VPDC). The mostly confined carbonate aquifer (Ozark Plateaus aquifers system, OZRK), has a large percentage of premodern water and the lowest proportion of modern groundwater of all the carbonate aquifers.

Unconsolidated alluvial basin-fill aquifers in semiarid to arid regions that are tapped by deep wells (Basin and Range basin fill, BNRF; Rio Grande, RIOG; High Plains, HPAQ) have small percentages of modern groundwater. The Central Valley aquifer (CVAL) system, which consists of unconsolidated alluvium, has a nearly equal amount of modern, mixed, and premodern groundwater, owing to the large amount of pumping and recharge resulting from irrigation and subsequent acceleration of groundwater flow in this aquifer. Semiconsolidated sand aquifers in the humid eastern United States (Mississippi Embayment/Texas Coastal Uplands, METX; Coastal Lowlands, COLL; Southeastern Coastal Plain, SECP; Northern Atlantic Coastal Plain, NACP) are all largely confined and predominantly contain premodern groundwater.

The unconsolidated glacial aquifers (GLAC) range across a large geographic area and include both arid and humid regions. In some areas, wells tap aquifers that are locally confined, but wells in the current study are largely unconfined, shallow, and from more humid regions. Nearly three quarters of the wells in the glacial aquifers were found to contain modern groundwater.

This method provides an unbiased estimate of the proportion of modern, mixed, and premodern groundwater in an aquifer used for (in this case) public supply (Belitz and others, 2010), when applied to a set of wells that are spatially distributed among equal-area grids covering the principal aquifer of interest. And when compared broadly among the principal aquifers supplying more than 70 percent of the groundwater used as a source of public supply in the United States (Maupin and Barber, 2005), the relative vulnerability of aquifers can be compared nationally.

The efficacy of the tritium-based age classification system can also be evaluated at a regional scale. Results from the SECP are plotted as a function of relative distance from the outcrop zone and relative depth (as defined by Brown and others, 2019; fig. 4). As expected, the locations where groundwater was classified as modern are near the outcrop area and relatively shallow. All of the modern groundwater ages are located in the nearest 20 percent of the distance from the outcrop area and the shallowest 10 percent of the aquifer system. Of the groundwater samples with mixed ages, most sites were relatively shallow and near the outcrop area. The two mixed samples that are farthest from the outcrop (circles with bold outline in fig. 4) are from relatively shallow wells. Some wells near the outcrop are classified as premodern, but groundwater ages can be premodern near the outcrop if the aquifer is confined.

\section{Nested Pairs of Well Networks with Varying Depths and Climate Conditions}

The efficacy of the tritium-based age classification system can be also be evaluated using data from paired (co-located) networks of relatively shallow monitoring wells and deeper domestic wells. From 1997 to $2016,{ }^{3} \mathrm{H}$ data were analyzed in samples from 287 wells collected from 5 paired networks (10 total networks). Results for the five pairs of nested monitoring wells and domestic-supply/public-supply networks that span a range of climatic conditions are shown in figure 5. Hydrogeologic principles predict that in the paired networks, shallow monitoring wells would have more modern water than their paired deeper domestic wells, and groundwater from wells in more humid areas would have more modern water than groundwater from wells in more arid regions. The results show that, at the network level, the amount of modern water generally decreases from humid to arid and from shallow to deep, as the amount of premodern water increases across those same categories. The high percentage of modern groundwater in the shallow network in Utah, a semiarid region, may be related to the fact that much of the recharge in that area is from the nearby mountain front that has high precipitation rates (50 inches per year), and lawns and gardens in this urban area are irrigated (Thiros and Manning, 2004).

\section{Public-supply Well Results Compared to Results of Other Age-dating Studies}

Results of age-dating from 14 previous studies are available for comparison to results from the tritium-based age classification system developed in this study (table 1, fig. 6). Apparent ages or categories from the previous studies are translated to the categories of modern, mixed, or premodern as closely as possible for comparison purposes. For the previous studies, groundwater with recharge dated prior to 1953 was considered premodern, recharge dates of 1953 or later were considered modern, and if the previous study indicated mixtures of modern and premodern water, those data were compared to our mixed category. For five of the previous studies, it was not possible to determine a mixed category. For those five studies, data are plotted as 0 percent mixed on the $y$-axis of figure $6 B$, but we discuss the effect that having a mixed category may have had on the results.

Some of the previous studies include samples from targeted areas within an aquifer, whereas this study collected samples distributed across the entire aquifer. In those cases, data from the previous studies are compared to the appropriate subset of data from the principal aquifer studies. Depth data are available for 7 of the 15 studies that are compared to the 


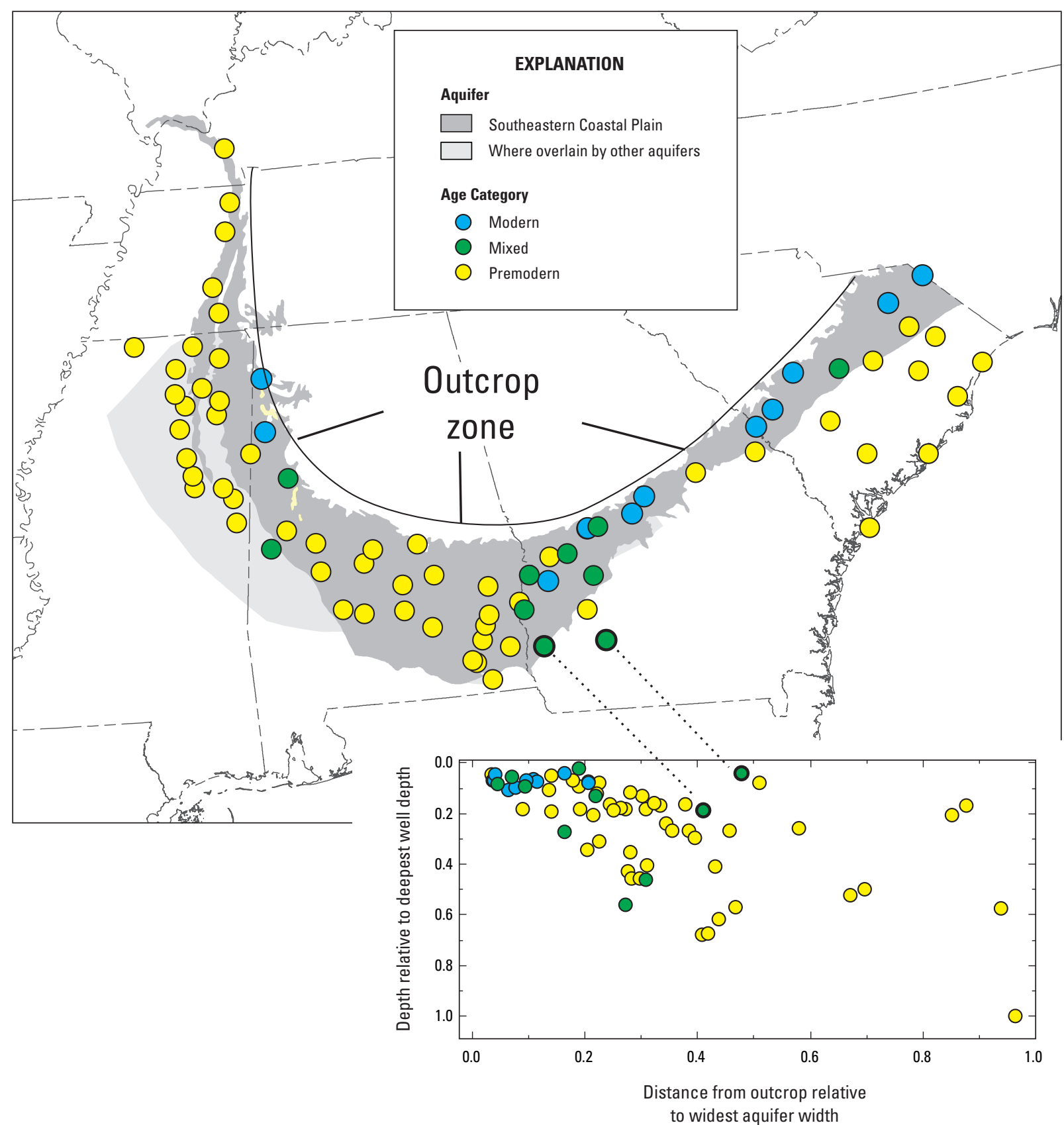

Figure 4. Locations of modern, mixed, and premodern groundwater for samples from the Southeastern Coastal Plain aquifer system across a range of depths and distances from the outcrop area. Circles with bold outlines represent the two mixed-age groundwater samples farthest from the outcrop zone. Note that the wells are relatively shallow.

current study; for 3 of the remaining 8 studies, summary statistics such as range of depths or median depths are available, and 5 of the studies have no depth data available. Some of the observed differences in age categories may be related to differences in well depths in the studies being compared.

A comparison of this study to previous studies indicates good correspondence between results. Note that all study numbers and descriptions are listed in table 1. Seven of the
14 studies of wells containing modern groundwater have results close (distance from the line less than 10 percent) to the 1:1 correlation line (fig. $6 \mathrm{~A}$ ). The exceptions are studies 4, 7, $10,12,13$, and 14 , for which the departure from the 1:1 line is less than 20 percent, and study 5 , which differs from other studies by a large margin. For five of the comparison studies it is not possible to evaluate the mixed water category; of the remaining nine studies, four are close to the 1:1 line, three are 


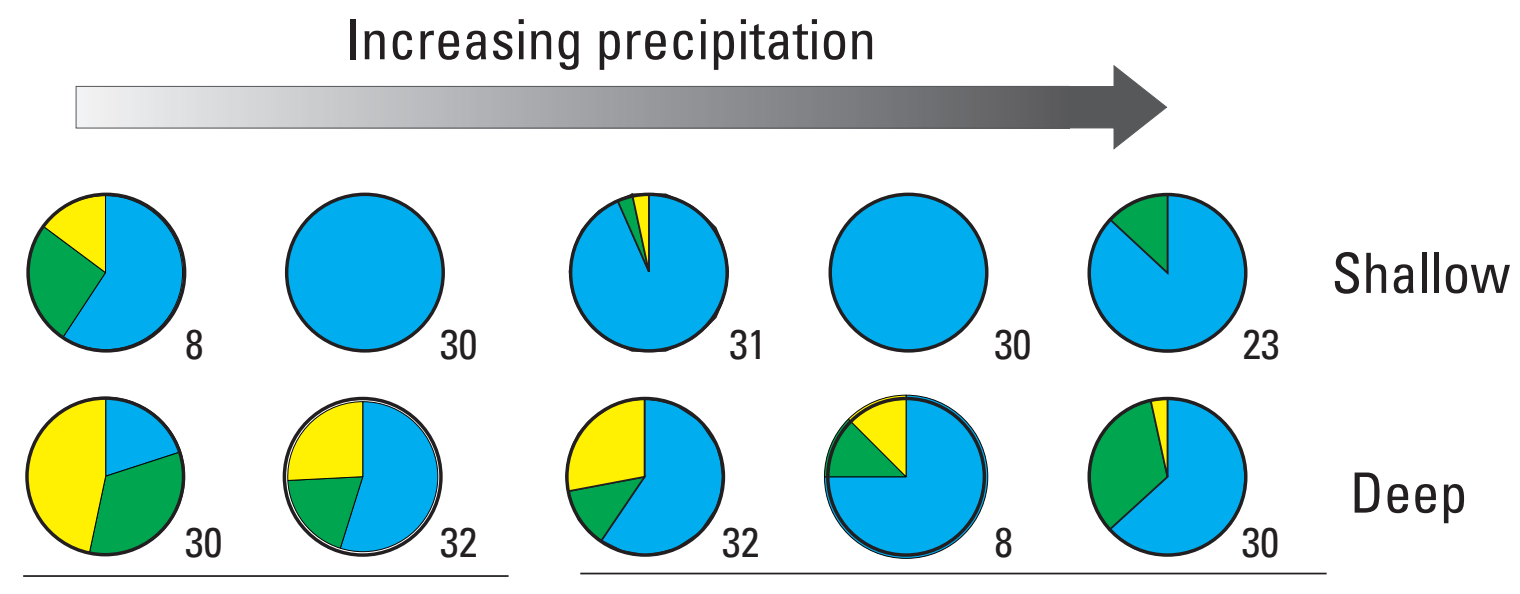

\section{Basin-fill Aquifers}

NEVADA

UTAH

Glacial Aquifers

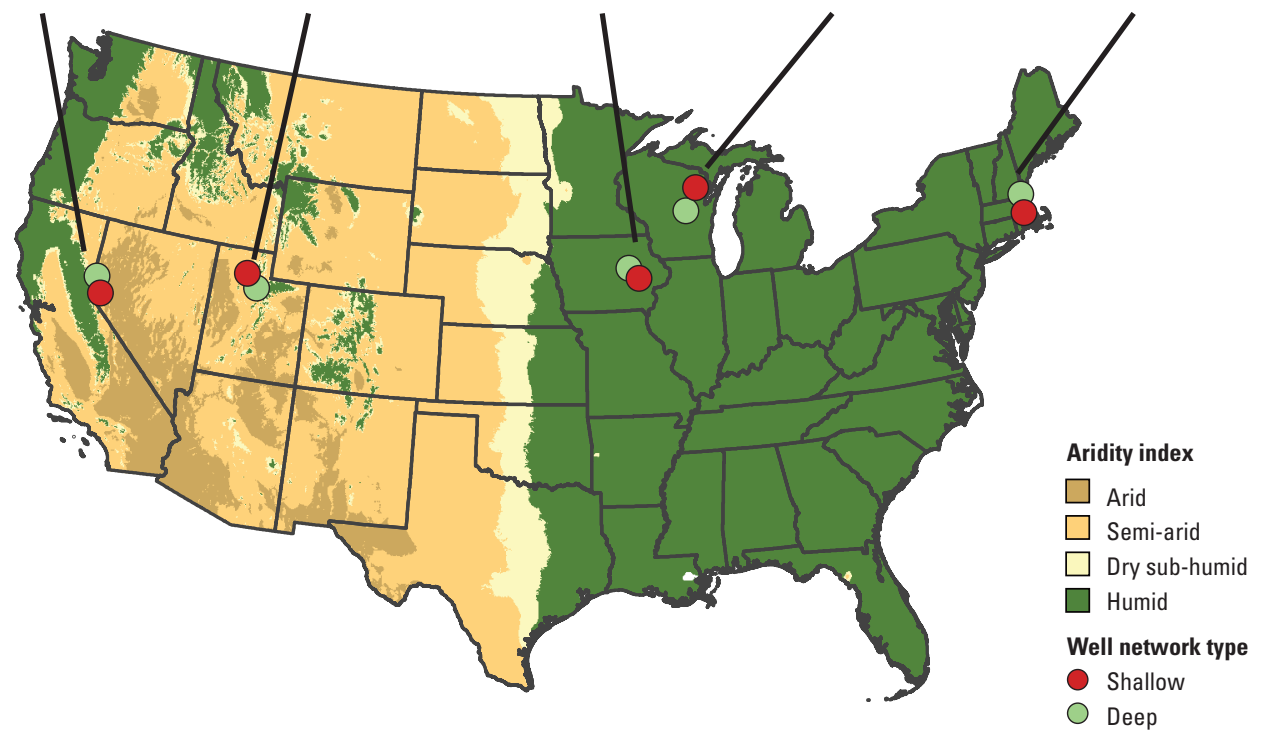

EXPLANATION

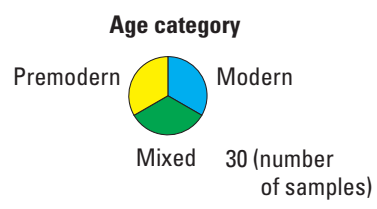

Figure 5. Locations of paired well networks used to compare tritium $\left({ }^{3} \mathrm{H}\right)$ category results across a range of depth and climate conditions, and pie charts showing proportions of modern, mixed, and premodern groundwater for samples from those networks. Climate zones from Zomer and others $(2007,2008)$.

within 20 percent departure from the 1:1 line, and two differ by larger margins (fig. 6B). In the comparison of premodern groundwater (fig. 6C), 6 of the 13 studies have little or no premodern groundwater (studies 1, 4, 9, 10, 12, and 13). Of the remaining eight studies, two are close to the 1:1 line (studies 2 and 5), four are further from the 1:1 line but within 20 percent (studies 3a, 3b, 7, and 11), and three demonstrate as much as a 35 percent departure from the 1:1 line (studies 6, 8, and 14).

Expected patterns based on hydrologic principles seen in this study are also observed in previous studies. In both the previous studies and this study, unconfined carbonate-rock aquifers and fractured rock aquifers in humid regions (studies 1, 4, 9, 10,12, and 13) had predominantly modern groundwater and little to no premodern groundwater (fig. 6A,C). The work in the Basin and Range carbonate-rock aquifer (study 2), located in an arid region, had similar results in both studies: relatively equal proportions of modern and premodern groundwater and a small percentage of mixed groundwater. Premodern groundwater was predominant in all studies of confined or mostly confined aquifers (studies 3a, 6, 7,8 , and 11). In this study, a lower percentage of premodern groundwater was found in the confined Floridan and confined Ozark Plateaus aquifer systems (studies 6 and 8), when compared to the other confined aquifers. These two aquifer systems also had large mismatches between the previous studies and the current study, likely owing to the lack of a mixed 


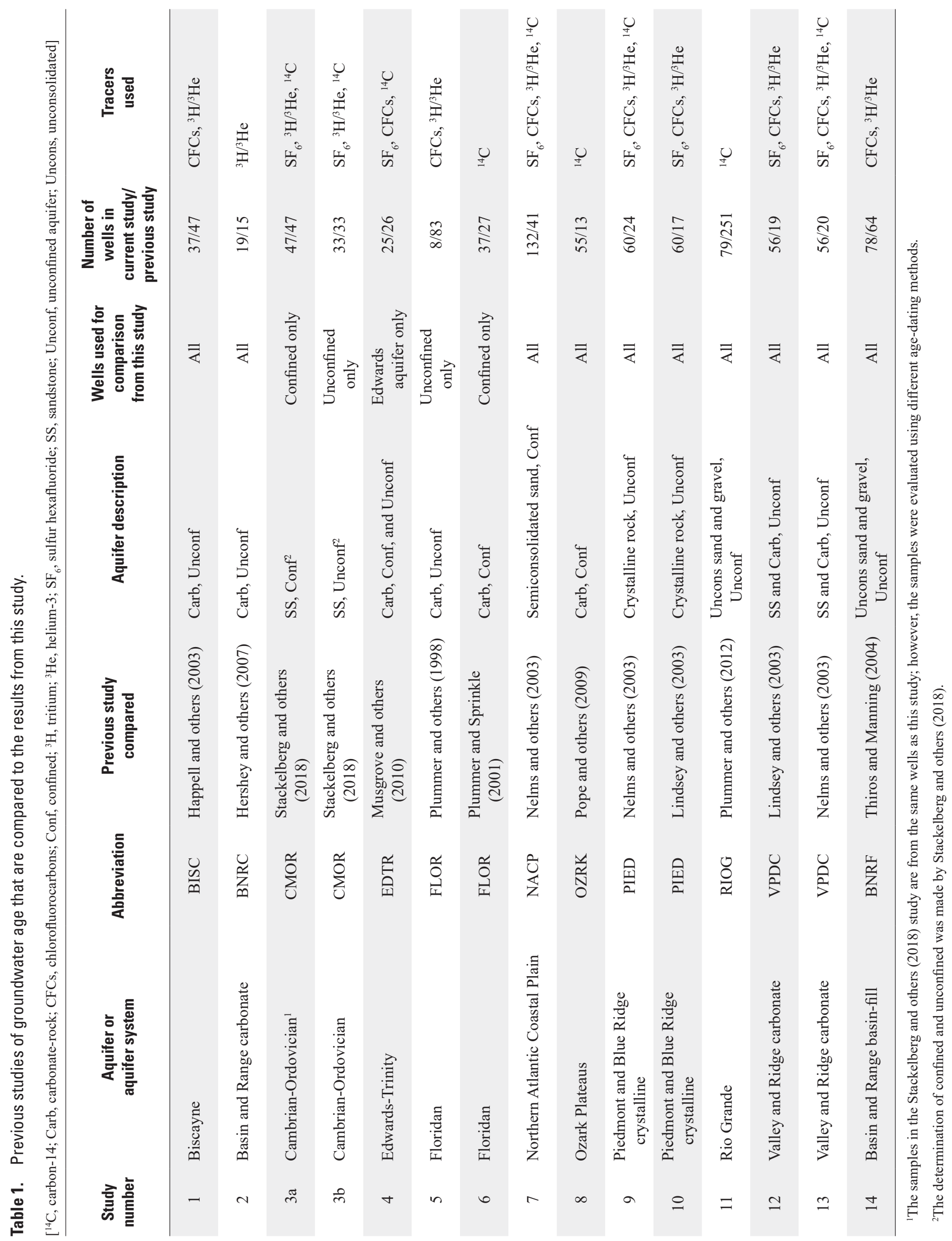




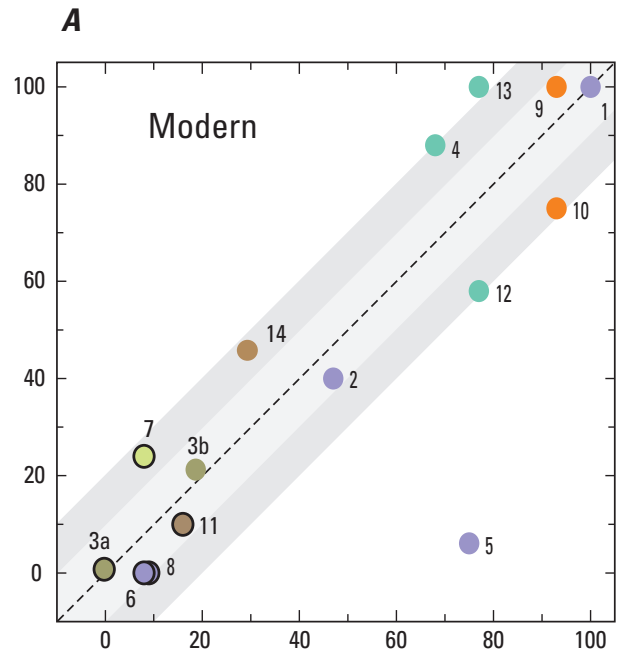

B
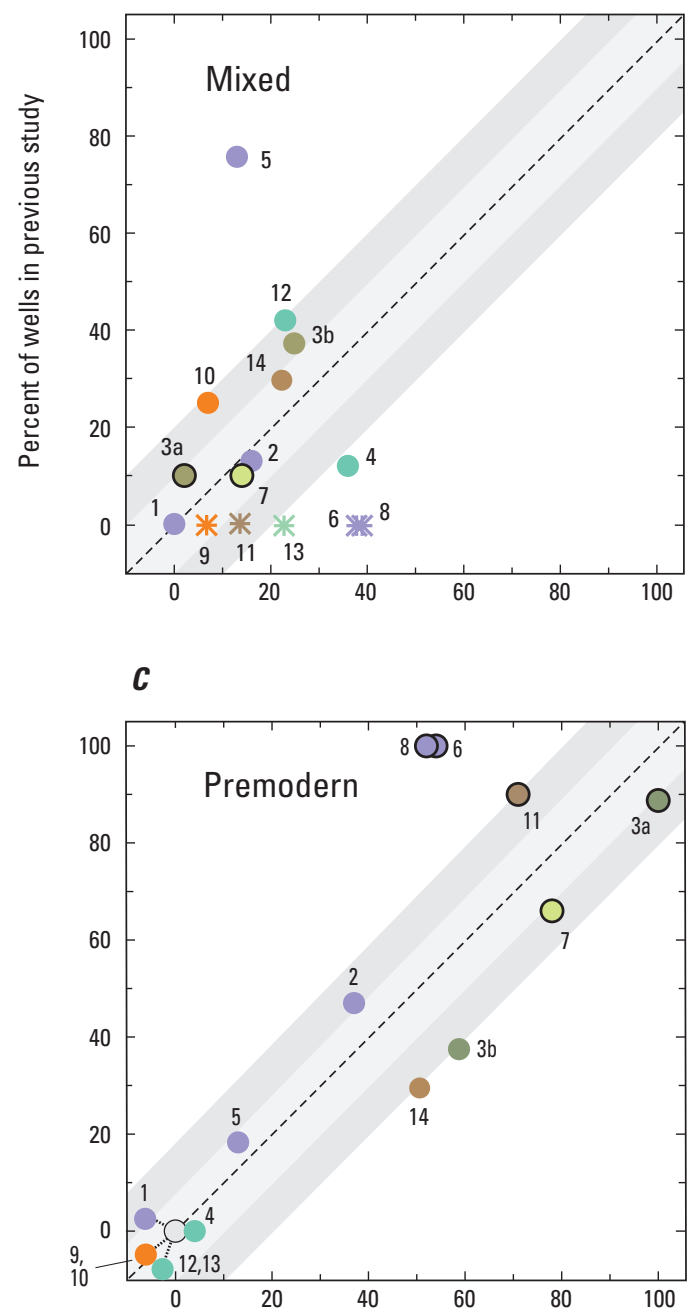

Percent of wells in category for current study

Figure 6. Percentage of wells in the categories of modern, mixed, and premodern groundwater in this study compared to previous studies in the same aquifer. Previous study numbers are presented in table 1.

\section{EXPLANATION}

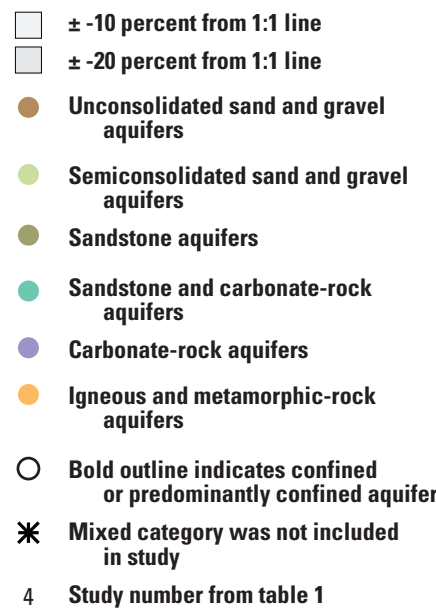

category in the previous studies, although mixing of groundwater of different ages would not be unusual in these aquifers. The largest mismatch between this study and previous studies was for the mixed and modern categories for the unconfined Floridan aquifer system (study 5). A large percentage of sites in the previous study were classified as mixed, likely because the previous study was localized and focused on evaluating mixtures of premodern groundwater, vertical infiltration, and river sources. The percentage of premodern groundwater in the unconfined Floridan aquifer system were similar in both studies. Studies 6, 8, 9, 11, and 13 appear to have the largest differences between previous studies and the current study, largely because they lack a mixed category.

There is an apparent pattern in which previous studies in carbonate-rock aquifers overestimate the percentage of premodern groundwater; evaluating mixtures might improve the understanding of groundwater age in those areas. All but one of these previous studies are from different sets of wells than the current study, so we would not expect the results to match exactly. For studies with well depth information, differences in well depth did not explain differences in age categories; some networks had similar age categories despite differences in depth. However, differences in confinement made the greatest difference in age categories within an aquifer, and as much as possible, comparisons were made among wells with similar confinement.

Using TracerLPM, Stackelberg and others (2018) interpreted multiple age-tracer datasets from the same wells in the Cambrian-Ordovician (CMOR) aquifer system as were used in this study. Designations of wells as unconfined and confined, as determined by Stackelberg and others (2018), were used to separate the data in the current study prior to comparing results (study numbers $3 a$ and $3 b$ in fig. 6). Overall, there are 
slight differences in results, largely because TracerLPM designated some samples with less than 5 percent modern water as mixtures, whereas the tritium-based age classification system in this study classified them as premodern.

\section{Comparison to Similar Approaches}

We compare the method presented herein to similar studies to highlight the distinctions between the tritiumbased age classification system and other approaches. If one were to establish a threshold of $0.5 \mathrm{TU}$ as indicative of the distinction between premodern and modern groundwater, then about 20 percent of the data classified as mixed in the current study would have been classified as modern or premodern, with about half of the data in each of those categories. None of the samples categorized as modern or premodern in the current study would change categories from premodern to modern, or the converse, if one were to use the single threshold of $0.5 \mathrm{TU}$. The value of the tritium-based age classification system, then, is that it identifies mixed samples as having a component of modern and premodern groundwater, which is important in interpreting susceptibility to anthropogenic contaminants and geochemical processes. Because of the spatial and temporal variation of ${ }^{3} \mathrm{H}$ in precipitation, a single threshold method would produce different errors with samples collected at different times and different geographic locations. The single threshold could underestimate the amount of premodern groundwater in locations and time periods with higher than average ${ }^{3} \mathrm{H}$ in precipitation and could overestimate the proportion of premodern groundwater in locations and time periods of lower than average ${ }^{3} \mathrm{H}$ in precipitation.

Jasechko (2016) developed an approach that determines the fraction of modern water in a mixed sample. Although the fraction of modern water could be valuable information, the method herein differs from that of Jasechko (2016) in that it is simplified by determining three categories representing modern, premodern, and mixed groundwater. Jasechko (2016) uses an average of decay-corrected tritium values from 1952 to the date of sampling to determine the threshold for classifying recharge as being 1953 or later, whereas this study selects the lowest decay-corrected post-peak ${ }^{3} \mathrm{H}$ concentration as the threshold for classifying recharge as 1953 or later. This distinction results in a lower threshold for modern groundwater in our method (fig. $7 A, B$ ). In addition, because of the lack of actual measurements prior to nuclear bomb testing, we use a range of recent apparent background concentrations to estimate the pre- $1953{ }^{3} \mathrm{H}$ concentrations and the threshold for premodern groundwater. The thresholds used herein could be used in the equation by Jasechko (2016) to determine the fraction of modern water. Jasechko (2016) uses a global ${ }^{3} \mathrm{H}$ precipitation record that varies both spatially and temporally; however, data from Michel and others (2018) that are computed at finer temporal (biannual) and spatial scales than previous work in the CONUS could be used with Jasechko's method as well.
Manning and others (2005) and Thiros and Manning (2004) used methods to create categories similar to modern, mixed, and premodern; however, those studies used other available tracers to first determine a recharge date, then compared the initial ${ }^{3} \mathrm{H}$ in the sample to the concentration of ${ }^{3} \mathrm{H}$ in precipitation on the recharge date. The method presented in this study does not require calculating groundwater age with other tracers prior to assigning the categories, and also describes methods for determining the upper and lower thresholds that vary in both space and time. It is noteworthy, however, that Manning and others (2005) and Thiros and Manning (2004) found the categories of modern, mixed, and premodern to be effective in explaining the proportion of wells affected by anthropogenic contaminants and concentrations of nitrate.

\section{Limitations}

Although the ${ }^{3} \mathrm{H}$ data from Michel and others (2018) for the $2^{\circ}$ latitude by $5^{\circ}$ longitude sections provide reasonable estimates of ${ }^{3} \mathrm{H}$ in precipitation across the CONUS, these data can deviate locally as a result of precipitation or seasonal irrigation patterns. Local precipitation patterns have become more important in recent years in influencing local ${ }^{3} \mathrm{H}$ inputs, as global ${ }^{3} \mathrm{H}$ values in precipitation have increasingly returned to natural levels. Therefore, measurements of ${ }^{3} \mathrm{H}$ in local precipitation, in conjunction with long-term historical records such as Vienna and Ottawa, can provide better estimates of ${ }^{3} \mathrm{H}$ deposition.

Thresholds for identifying modern groundwater based on ${ }^{3} \mathrm{H}$, as defined in this study, can misclassify groundwater in the modern category if recharge occurred during the time of peak ${ }^{3} \mathrm{H}$ concentrations introduced into the atmosphere in the early 1960s. As illustrated by the orange mixing line in figure $7 \mathrm{~A}$, mixtures of modern water, recharged around the time of peak ${ }^{3} \mathrm{H}$ concentrations, and premodern water can have concentrations of ${ }^{3} \mathrm{H}$ above the modern threshold and therefore be misclassified as modern when as little as 20 percent of the water is composed of modern groundwater. This potential error, however, is limited to the area under the peak of ${ }^{3} \mathrm{H}$ concentrations and as time moves forward this area will become smaller and less of an issue. Dispersion also decreases peak ${ }^{3} \mathrm{H}$ concentrations in groundwater as recharge from the time of peak ${ }^{3} \mathrm{H}$ concentrations mixes with groundwater of other ages. Another potential misclassification shown in figure $7 B$ is for samples of very young groundwater $\left(<15\right.$ years) with ${ }^{3} \mathrm{H}$ concentrations above the modern threshold, but with a small fraction of premodern groundwater - typically less than 30 percent - that should be classified as mixed. Since the water is predominately composed of modern water, the effect of the misclassification is minor; however, as time moves forward the potential for misclassification of this kind will grow.

As with any tritium-based method to classify age or compute fractions for recharge of 1953 or later water, the error or misclassification will grow with time, and ${ }^{3} \mathrm{H}$ alone will be less useful to classify or compute ages of groundwater in the future. We estimate this method will be useful until about 
$\boldsymbol{A}$

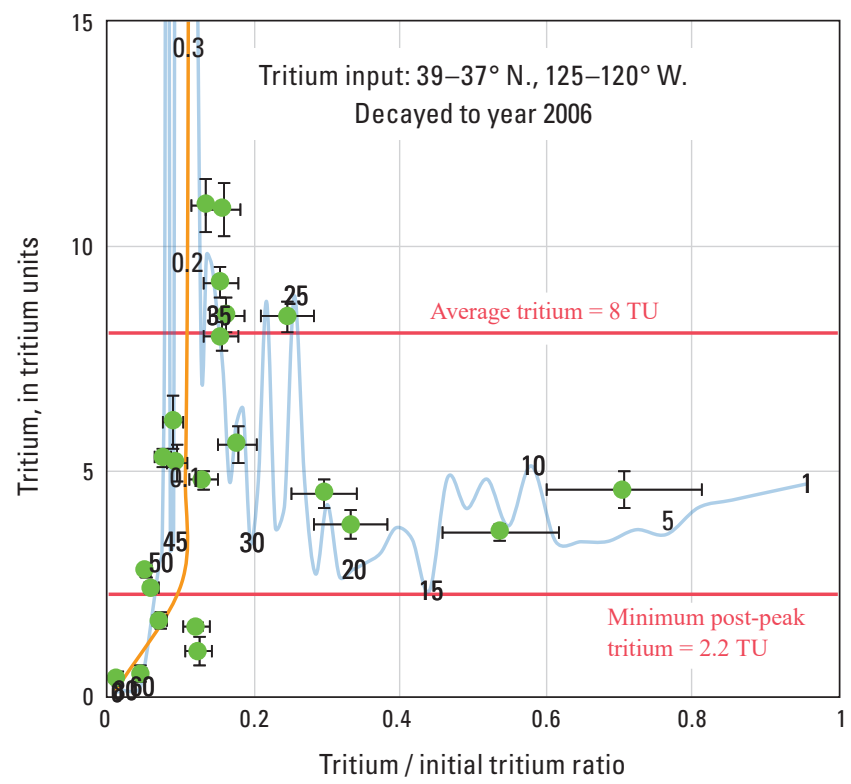

$B$

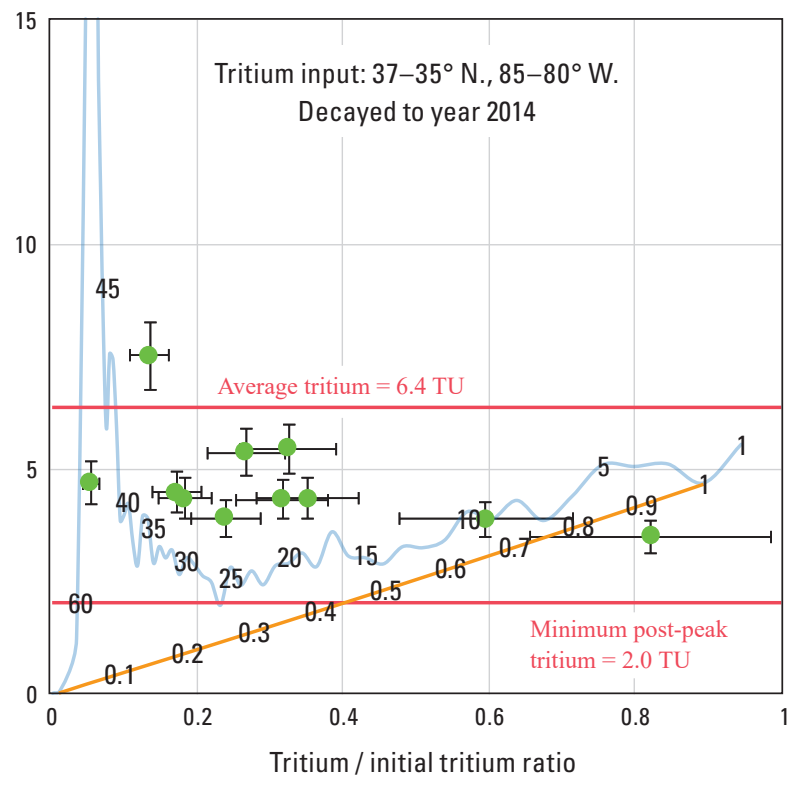

EXPLANATION

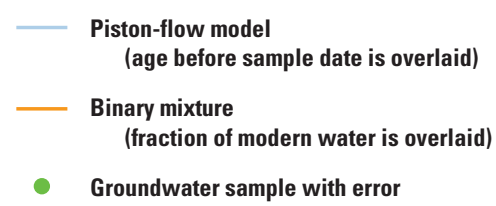

Figure 7. Plots of tritium and the tritium/initial tritium ratio for sites where helium isotopes were collected and used to compute tritiogenic helium-3 concentrations. The blue line is the piston-flow concentration of tritium and tritium/initial tritium ratio for groundwater samples collected in $(A) 2006$ near latitude-longitude quadrangle 39-37 N., 125-120 W., and in $(B) 2014$ near the latitudelongitude quadrangle $37-35^{\circ} \mathrm{N}$., $85-80^{\circ} \mathrm{W}$. Orange lines are binary mixing lines between for groundwater recharged prior to 1953 and for groundwater recharged in 1953 or later. The green dots are groundwater samples collected in $(A) 2006$ and $(B) 2014$. The top red lines represent the average tritium concentration of groundwater recharged in 1953 or later (Jasechko, 2016) and the lower red lines represent the minimum post peak tritium concentration (this method).

2030, at which point the errors around calculations of the fraction for recharge prior to 1953 will be too large for meaningful classification. Consequently, ${ }^{3} \mathrm{H}$ combined with other tracers of modern water may be used to classify water recharged prior to 1953 .

This method also does not account for the effects of dispersion on ${ }^{3} \mathrm{H}$ concentrations, which occurs in most aquifers. Dispersion would smooth out interannual high and low ${ }^{3} \mathrm{H}$ concentrations in the ${ }^{3} \mathrm{H}$ precipitation curve used to select the minimum post-peak ${ }^{3} \mathrm{H}$ concentration threshold (fig. 7). Thus, the selection of a threshold using a piston-flow assumption method will give a lower modern threshold than if the precipitation curve had accounted for dispersion, and thus may overclassify samples as being in the modern category. However, a small amount of dispersion has been accounted for by averaging monthly ${ }^{3} \mathrm{H}$ over 6 -month intervals. These differences may be minor because the fraction of modern water in the sample is likely substantial in most cases. 


\section{Summary and Conclusions}

Tritium categories of premodern, modern, or mixed groundwater provide a basis for capturing the predominant class of groundwater age that might preclude the need for further analysis using additional tracers (for example, premodern water is not susceptible to modern contaminants), or might give indications as to what tracers would be useful to further evaluate groundwater age. The results have implications for the susceptibility of groundwater to surface contaminants or to natural contaminants. The method described herein requires a single ${ }^{3} \mathrm{H}$ sample from a well and a straightforward calculation to classify the groundwater as belonging to one of those three groups. The method considers both the spatial and temporal variation of ${ }^{3} \mathrm{H}$ in precipitation and is thus a more robust method for classifying groundwater age than using a single threshold of ${ }^{3} \mathrm{H}$ to classify groundwater age as modern or premodern. The method improves on previous methods by using modern measured concentrations to estimate pre-1953 background and by using the lowest value of ${ }^{3} \mathrm{H}$ from the time period following peak concentrations to estimate a modern threshold. The addition of a mixed category provides further understanding of ages that would be classified as modern or premodern using a binary classification system.

At a national scale, patterns of classified groundwater ages were consistent with expected age patterns based on a wide range of climatic regions, geographic regions, hydrogeologic settings, aquifers, and well depths. Shallow fractured bedrock and carbonate-rock aquifers in humid regions of the country have the largest proportion of modern groundwater, followed closely by the shallow unconsolidated glacial aquifers. Confined aquifers have the highest proportion of premodern water. Within aquifers that have variable conditions, confined parts of those aquifers consistently have more premodern water than the unconfined parts of those same aquifers. Premodern groundwater also occurs more frequently in arid regions than humid regions of the United States. The application of this method to a set of public-supply wells that are spatially distributed among equal-area grids covering each of 19 principal aquifers allows an unbiased national comparison of the susceptibility of these aquifers to anthropogenic and naturally occurring contaminants.

Patterns of classified groundwater ages also were consistent with spatial patterns of recharge and groundwater flow, and construction characteristics of different well types. When comparing shallow and deep networks of monitoring wells and domestic-supply wells across a range of climate regions, shallow wells consistently have a larger percentage of modern groundwater than deeper wells. In addition, groundwater near sources of recharge tend to have larger proportions of modern water than downgradient areas.

Although previous studies of groundwater age typically do not represent the same regions as the current study, we find the current results generally match well with the results of previous studies. The method presented herein represents a new method to classify groundwater age as modern, mixed, or premodern based on ${ }^{3} \mathrm{H}$ values alone.

\section{References Cited}

Belitz, K., Dubrovsky, N.M., Burow, K.R., Jurgens, B.C., and Johnson, T.D., 2003, Framework for a groundwater quality monitoring and assessment program for California: U.S. Geological Survey Water-Resources Investigations Report 03-4166, $78 \mathrm{p}$.

Belitz, K., Jurgens, B.C., Landon, M.K., Fram, M.S., and Johnson, T.D., 2010, Estimation of aquifer scale proportion using equal area grids - Assessment of regional scale groundwater quality: Water Resources Research, v. 46, 14 p., accessed December 2013 at http://dx.doi. org/10.1029/2010WR009321.

Böhlke, J.K., and Denver, J.M., 1995, Combined use of groundwater dating, chemical, and isotopic analyses to resolve the history and fate of nitrate contamination in two agricultural watersheds, Atlantic Coastal Plain, Maryland: Water Resources Research, v. 31, no. 9, p. 2319-2339. [Also available at https://doi.org/10.1029/95WR01584.]

Broers, H.P., 2004, The spatial distribution of groundwater age for different geohydrological situations in the Netherlands - Implications for groundwater quality monitoring at the regional scale: Journal of Hydrology, v. 299, p. 84-106, accessed September 2009 at https://doi.org/10.1016/j.jhydrol.2004.04.023.

Brown, C.J., Barlow, J.R.B., Cravotta, C.A., and Lindsey, B.D., 2019, Factors affecting the occurrence of lead and manganese in untreated drinking water from Atlantic and Gulf Coastal Plain aquifers, eastern United States-Dissolved oxygen and $\mathrm{pH}$ framework for evaluating risk of elevated concentrations: Applied Geochemistry, v. 101, p. 88-102, accessed May 2019 at https://doi.org/10.1016/j. apgeochem.2018.10.017.

Busenberg, E., and Plummer, L.N., 2000, Dating young ground water with sulfur hexafluoride-Natural and anthropogenic sources of sulfur hexafluoride: Water Resources Research, v. 36, no. 10, p. 3011-3030. [Also available at https://doi.org/10.1029/2000WR900151.]

Eastoe, C.J., Watts, C.J., Ploughe, M., and Wright, W.E., 2012, Future use of tritium in mapping pre-bomb groundwater volumes: Groundwater, v. 50, no. 1, p. 87-93.

Happell, J.D., Price, R.M., Top, Z., and Swart, P.K., 2003, Evidence for the removal of CFC-11, CFC-12, and CFC-113 at the groundwater-surface water interface in the Everglades: Journal of Hydrology, v. 279, p. 94-105, accessed June 2018 at https://doi.org/10.1016/S0022-1694(03)00169-0. 
Hershey, R.L., Heilweil, V.M., Gardner, P., Lyles, B.F., Earman, S., Thomas, J.M., and Lundmark, K.W., 2007, Ground-water chemistry interpretations supporting the Basin and Range Regional Carbonate-rock Aquifer System (BARCAS) study, eastern Nevada and western Utah: Desert Research Institute Publication No. 41230, 86 p.

International Atomic Energy Agency, 2017, Water isotope system for data analysis, visualization, and electronic retrieval: The WISER database, accessed February 2018 at http:// www-naweb.iaea.org/napc/ih/IHS_resources_isohis.html.

Jasechko, S., 2016, Partitioning young and old groundwater with geochemical tracers: Chemical Geology, v. 427, p. 35-42, accessed March 2018 at http://dx.doi. org/10.1016/j.chemgeo.2016.02.012.

Jurgens, B.C., Böhlke, J.K., and Eberts, S.M., 2012, TracerLPM (Version 1)-An Excel ${ }^{\circledR}$ workbook for interpreting groundwater age distributions from environmental tracer data: U.S. Geological Survey Techniques and Methods Report 4-F3, 60 p., accessed March 2014 at https://pubs. usgs.gov/tm/4-f3/.

Landon, M.K., and Belitz, K., 2012, Geogenic sources of benzene in aquifers used for public supply, California: Environmental Science and Technology, v. 46, no. 16, p. 8689-8697, accessed April 2018 at http://dx.doi. org/10.1021/es302024c.

Lindsey, B.D., Ayotte, J.D., Jurgens, B.C., and Desimone, L.A., 2017, Using groundwater age distributions to understand changes in methyl tert-butyl ether (MtBE) concentrations, northeastern United States: Science of the Total Environment, v. 579, p. 579-587. [Also available at http:// dx.doi.org/10.1016/j.scitotenv.2016.11.058.]

Lindsey, B.D., Jurgens, B.C., and Belitz, K., 2019, Data for using tritium as an indicator of modern, mixed and premodern groundwater age: U.S. Geological Survey data release, https://doi.org/10.5066/P9DU94RV.

Lindsey, B.D., Phillips, S.W., Donnelly, C.A., Speiran, G.K., Plummer, L.N., Böhlke, J.K., Focazio, M.J., Burton, W.C., and Busenberg, E., 2003, Residence times and nitrate transport in ground water discharging to streams in the Chesapeake Bay watershed: U.S. Geological Survey WaterResources Investigations Report 03-4035, 201 p. [Also available at https://doi.org/10.3133/wri034035.]

Lucas, L.L., and Unterweger, M.P., 2000, Comprehensive review and critical evaluation of the half-life of tritium: Journal of Research of the National Institute of Standards and Technology, v. 105, no. 4, p. 541-549.
Manning, A.H., Solomon, K.D., and Thiros, S.A., 2005, ${ }^{3} \mathrm{H} /{ }^{3} \mathrm{He}$ age data in assessing the susceptibility of wells to contamination: Ground Water, v. 43, no. 3, p. 353-367, accessed April 2019 at https://doi.org/10.1111/j.17456584.2005.0028.x.

Maupin, M.A., and Barber, N.L., 2005, Estimated withdrawals from principal aquifers in the United States, 2000: U.S. Geological Survey Circular 1279, 46 p. [Also available at https://doi.org/10.3133/cir1279.]

McMahon, P.B., 2012, Use of classes based on redox and groundwater age to characterize the susceptibility of principal aquifers to changes in nitrate concentrations, 1991 to 2010: U.S. Geological Survey Scientific Investigations Report 2012-5220, 41 p., accessed May 2018 at https://doi. org/10.3133/sir20125220.

McMahon, P.B., Burow, K.R., Kauffman, L.J., Eberts, S.M., Böhlke, J.K., and Gurdak, J.J., 2008, Simulated response of water quality in public supply wells to land use change: Water Resources Research, v. 44, no. W00A06, 16 p., accessed May 2018 at https://doi. org/10.1029/2007WR006731.

McMahon, P.B., Plummer, L.N., Böhlke, J.K., Shapiro, S.D., and Hinkle, S.R., 2011, A comparison of recharge rates in aquifers of the United States based on groundwaterage data: Hydrogeology Journal, v. 19, no. 4, p. 779-800, accessed May 2018 at https://doi.org/10.1007/s10040-0110722-5.

Michel, R.L., 1989, Tritium deposition in the continental United States, 1953-83: U.S. Geological Survey WaterResources Investigations Report 89-4072, 46 p., accessed December 2017 at https://doi.org/10.3133/wri894072.

Michel, R.L., Jurgens, B.C., and Young, M.B., 2018, Tritium deposition in precipitation in the United States, 1953-2012: U.S. Geological Survey Scientific Investigations Report 2018-5086, 11 p., accessed October 2018 at https://doi. org/10.3133/sir20185086.

Mook, W.G., 1980, Carbon-14 in hydrogeological studies, in Fontes, J.Ch., ed., Handbook of environmental isotope geochemistry, volume 1: Netherlands, Elsevier, 588 p.

Musgrove, M., Fahlquist, L.S., Houston, N.A., Lindgren, R.J., and Ging, P.B., 2010, Geochemical evolution processes and water-quality observations based on results of the National Water-Quality Assessment Program in the San Antonio segment of the Edwards aquifer, 1996-2006: U.S. Geological Survey Scientific Investigations Report 2010-5129, 93 p., accessed October 2018 at https://doi.org/10.3133/ sir20105129. 
Nelms, D.L., Harlow, G.E., Jr., Plummer, L.N., and Busenberg, E., 2003, Aquifer susceptibility in Virginia, 1998-2000: U.S. Geological Survey Water-Resources Investigations Report 03-4278, 58 p., accessed October 2018 at https://pubs.usgs.gov/wri/wri034278/wrir03_4278. pdf.

Plummer, L.N., Bexfield, L.M., Anderholm, S.K., Sanford, W.E., Busenberg, and E., 2012, Geochemical characterization of ground-water flow in the Santa Fe Group aquifer system, Middle Rio Grande Basin, New Mexico (ver. 1.2, November 20, 2012): U.S. Geological Survey WaterResources Investigations Report 03-4131, 395 p., accessed October 2018 at https://doi.org/10.3133/wri034131.

Plummer, L.N., and Busenberg, E., 1999, Chlorofluorocarbons, in Cook, P., and Herczeg, A., eds., Environmental tracers in subsurface hydrology, chapter 15: Amsterdam, Kluwer Academic Press, p. 441-478.

Plummer, L.N., Busenberg, E., Drenkard, P., Schlosser, P., Ekwurzel, B., Weppernig, R., McConnell, J.B., and Michel, R.L., 1998, Flow of river water into a karstic limestone aquifer-2. Dating the young fraction in groundwater mixtures in the Upper Floridan aquifer near Valdosta, Georgia: Applied Geochemistry, v. 13, no. 8, p. 1017-1043, accessed April 2018 at https://doi.org/10.1016/S08832927(98)00032-8.

Plummer, L.N., and Sprinkle, C.L., 2001, Radiocarbon dating of dissolved inorganic carbon in groundwater from confined parts of the Upper Floridan aquifer, Florida, USA: Hydrogeology Journal, v. 217, p. 127-150, accessed April 2018 at https://doi.org/10.1007/s100400000121.

Pope, L.M., Mehl, H.E., and Coiner, R.L., 2009, Quality characteristics of ground water in the Ozark aquifer of northwestern Arkansas, southeastern Kansas, southwestern Missouri, and northeastern Oklahoma, 2006-07: U.S. Geological Survey Scientific Investigations Report 2009-5093, 60 p., accessed April 2018 at https://doi.org/10.3133/ sir20095093.

Sanford, W.E., 2011, Calibration of models using groundwater age: Hydrogeology Journal, v. 19, p. 13-16, accessed April 2018 at https://doi.org/10.1007/s10040-010-0637-6.

Schlosser, P., Stute, M., Dorr, H., Sonntag, C., and Munnich, K.O., 1988, Tritium $/{ }^{3} \mathrm{He}$ dating of shallow groundwater: Earth and Planetary Science Letters, v. 89, p. 353-362, accessed June 2018 at https://doi.org/10.1016/0012$821 X(88) 90122-7$.

Scott, J.C., 1990, Computerized stratified random site-selection approaches for design of a ground-water-quality sampling network: U.S. Geological Survey Water-Resources Investigations Report 90-4101, 109 p. [Also available at https://pubs.er.usgs.gov/publication/wri904101.]
Seifert, D., Sonnenborg, T.O., Scharling, P., and Hinsby, K., 2007, Use of alternative conceptual models to assess the impact of a buried valley on groundwater vulnerability: Hydrogeology Journal, v. 16, p. 659-674, accessed April 2018 at https://doi.org/10.1007/s10040-007-0252-3.

Sheets, R.A., Bair, E.S., and Rowe, G.L., 1998, Use of ${ }^{3} \mathrm{H} /{ }^{3} \mathrm{He}$ ages to evaluate and improve ground-water flow models in a complex buried-valley aquifer: Water Resources Research, v. 34, no. 5, p. 1077-1089, accessed May 2009 at https:// doi.org/10.1029/98WR00007.

Solomon, D.K., Poreda, R.J., Schiff, S.L., and Cherry, J.A., 1992, Tritium and helium 3 as groundwater age tracers in the Borden Aquifer: Water Resources Research, v. 28, no. 3, p. 741-755, accessed February 2018 at https://doi. org/10.1029/91WR02689.

Stackelberg, P.E., Szabo, Z., and Jurgens, B.C., 2018, Radium mobility and the age of groundwater in publicdrinking-water supplies from the Cambrian-Ordovician aquifer system, north-central USA: Applied Geochemistry, v. 89, p. 34-48, accessed December 2017 at https://doi. org/10.1016/j.apgeochem.2017.11.002.

Starn, J.J., Bagtzoglou, A.C., and Robbins, G.A., 2010, Using atmospheric tracers to reduce uncertainty in groundwater recharge areas: Groundwater, v. 48, no. 6, p. 858-868, accessed May 2010 at https://doi.org/10.1111/j.17456584.2010.00674.x.

Stewart, G.L., and Hoffman, C.M., 1966, Tritium rainout over the United States in 1962 and 1963: U.S. Geological Survey Circular 560, $11 \mathrm{p}$.

Sudicky, E.A., and Frind, E.O., 1981, Carbon 14 dating of groundwater in confined aquifers - Implications of aquitard diffusion: Water Resources Research, v. 17, no. 4, p. 1060-1064, accessed April 2018 at https://doi. org/10.1029/WR017i004p01060.

Thiros, S.A., and Manning, A.H., 2004, Quality and sources of ground water used for public supply in Salt Lake Valley, Salt Lake County, Utah, 2001: U.S. Geological Survey Water Resources Investigations Report 03-4325, 95 p.

Thomas, M.A., 2007, The association of arsenic with redox conditions, depth, and ground-water age in the glacial aquifer system of the northern United States: U.S. Geological Survey Scientific Investigations Report 2007-5036, 26 p., accessed May 2018 at https://doi.org/10.3133/sir20075036.

Turnadge, C., and Smerdon, B.D., 2014, A review of methods for modelling environmental tracers in groundwaterAdvantages of tracer concentration simulation: Journal of Hydrology, v. 519, p. 3674-3689, accessed April 2018 at http://dx.doi.org/10.1016/j.jhydrol.2014.10.056. 
U.S. Geological Survey, 2003, Principal aquifers of the 48 conterminous United States, Hawaii, Puerto Rico, and the U.S. Virgin Islands: U.S. Geological Survey dataset. [Also available at https://doi.org/10.3133/70046037.]

Vogel, J.C., 1967, Investigation of groundwater flow with radiocarbon, in Symposium on isotopes in hydrology, Vienna, Austria, Proceedings: Vienna, Austria, International Atomic Energy Agency, November 14-18, 1966, p. 355-369.

Zomer, R.J., Trabucco, A., Bossio, D.A., van Straaten, O., and Verchot, L.V., 2008, Climate change mitigation-A spatial analysis of global land suitability for clean development mechanism afforestation and reforestation: Agriculture, Ecosystems, and Environment, v. 26, p. 67-80, accessed May 2018 at http://dx.doi.org/10.1016/j.agee.2008.01.014.

Zomer, R.J., Trabucco, A., van Straaten, O., and Bossio, D.A., 2007, Carbon, land and water-A global analysis of the hydrologic dimensions of climate change mitigation through afforestation/reforestation: Colombo, Sri Lanka, International Water Management Institute Research Report 101, accessed May 2018 at http://dx.doi.org/10.3910/2009.101. 
For additional information, contact:

NAWQA Chief Scientist

U.S. Geological Survey

12201 Sunrise Valley Drive, MS 413

Reston, VA 20192-0002

Or visit our website at: https://water.usgs.gov/nawqa/ Email: nawqapublicinfo@usgs.gov

Publishing support provided by the West Trenton Publishing Service Center 


\section{这}

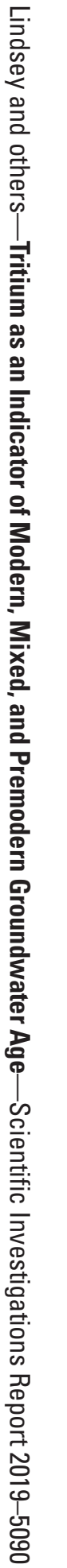

